Revista de Antropología Social

ISSN: $1131-558 \mathrm{X}$

\title{
Por qué en África no se reconoce la existencia de poblaciones indígenas. Un estudio de caso: los bubis de la isla de Bioko
}

\author{
Coro J-A Juanena ${ }^{1}$
}

Recibido: 6 de enero de 2016 / Aceptado: 15 de agosto de 2016

Resumen. En los estudios africanos europeos es frecuente negar la existencia de comunidades indígenas en África a pesar de que, al igual que el continente americano, África ha sido una región colonizada por Europa. Las nuevas identidades históricas y sociales creadas bajo la colonialidad del poder (Quijano, 2000), perduran en el imaginario político y académico hasta el punto de rechazar la condición indígena actual de una buena parte de los pueblos africanos. Esta cuestión está teniendo una gran relevancia en la política internacional tras el resurgir de la identidad indigena a escala global y en respuesta al sistema capitalista contemporáneo, fortalecida tras la aprobación de la Declaración de Derechos de los Pueblos Indígenas por la asamblea de Naciones Unidas en el año 2007. Mi objetivo en este artículo es deconstruir los procesos históricos que han llevado a rechazar la existencia actual de pueblos indígenas en el continente africano.

El caso de estudio descriptivo que propongo es el de la comunidad bubi, ubicada en la isla de Bioko, la cual se está presentando actualmente en la arena global como pueblo indígena y reclamando sus derechos inherentes. Este caso de estudio es especialmente interesante porque cumple con una doble condición: por una parte, el primer contacto del "encuentro colonial" de este pueblo africano coincide con el mismo periodo histórico en el que se produce el primer contacto y la creación de la id-entidad geocultural denominada América; por otro lado, la colonización efectiva del territorio y su denominación como indígenas será llevada a cabo por la misma id-entidad geocultural —la Europa ibérica一, aunque en diferentes momentos históricos.

Palabras clave: Identidad; indígena; colonialidad del poder; ideología de la representación; Bubis; otredad colonizada; postcolonial; África, América.

\section{[en] Why is the Existence of Indigenous People not Recognised in Africa? A Case Study: Bubis of Bioko Island}

\begin{abstract}
European African studies traditionally deny the existence of indigenous communities in Africa, despite the fact that in the same way as the American continent, Africa was once too a region colonised by Europe. The new social and historical identities created under the coloniality of power (Quijano, 2000), endure in the political and academic imagination to the extent of negating the current indigenous status of a large proportion of African nations. This issue is of great relevance in contemporary international politics due to the revival of the idea of the indigenous identity on a global scale and as an answer to modern capitalism, as reinforced by the United Nations Declaration on the Rights of Indigenous Peoples adopted by the UN General Assembly in 2007. My objective of this article is to deconstruct the historical processes that have resulted in the current denial of the existence of indigenous peoples on the African continent.
\end{abstract}

1 Kolonialismo Osteko Ikasketa Zentroa (KOIZ)

Grupo de Estudios Africanos (GEA-UAM)

koro@postcolonialstudies.org 
I propose a descriptive study of the Bubi community on the isle of Bioko, an ethnic group which is presently declaring its status as indigenous peoples and asserting its inherent rights in the global arena. This case is especially interesting as a study objective because on the one hand, the first "colonial encounter" of this African nation happens at the same time as it does in the geocultural id-entity called America and, on the other hand, although at different points in history, the effective colonisation of the territory and the designation of the peoples as indigenous is carried out in both cases by the same geocultural id-entity, namely Iberian Europe.

Keywords: Identity; indigenous; coloniality of power; ideology of representation; Bubee.

Sumario: 1. Introducción. 2. Re-conceptualizando la realidad: el contexto conceptual. 2.1 Introito 2.2 Dos formas diferentes de nombrar al Otr@ en el primer momento del "encuentro colonial". 2.3 La importancia del modelo de administración colonial y sus efectos a la hora de nombrar la otredad colonizada. Dos continentes: África y América; dos Europas: Ibérica y Europa occidental. 2.4 Los procesos de independencia y la re-construcción de las identidades postcoloniales. 3. El caso de estudio: la comunidad bubi ubicada en la isla de Bioko.3.1 Dos formas diferentes de nombrar al Otr@ en el primer momento del "encuentro colonial": La isla de Ferñao do Pó. 3.2 La importancia del modelo de administración colonial y sus efectos a la hora de situar la otredad colonizada. Fernando Poo y la colonización española. 3.3 Los procesos de independencia y la construcción de las identidades postcoloniales: de súbdit@s de la corona española a ciudadanos del Estado de Guinea Ecuatorial. 4. Conclusiones. 5. Referencias bibliográficas.

Cómo citar: Juanena, C. J-A. (2016). Por qué en África no se reconoce la existencia de poblaciones indígenas. Un estudio de caso: los bubis de la isla de Bioko, en Revista de Antropología Social 25(2), 389-420.

Todo lo que se construye entre estos animales llamados humanos, se construye, se idea y se basa sobre el lenguaje.

Llamo discurso a esta cosa que se fija, se cristaliza a través del lenguaje, que usa los recursos del lenguaje.

El nuevo orden del discurso del amo. (Lacan, 1972) ${ }^{2}$

\section{Introducción}

Con sorprendente tozudez los estudios africanos en Europa, más acusadamente en la Europa de origen latino, han negado tradicionalmente la condición indígena a una buena parte de los pueblos africanos pese a que, al igual que el continente americano, África ha sido una región colonizada por los europeos ${ }^{3}$. Ambos territorios - África

\footnotetext{
https://www.youtube.com/watch?v=C9yN0Ggij78

Me gustaría subrayar la palabra "tradicionalmente" ya que esta temática esta siendo motivo de un fuerte debate internacional, tanto en la academia como en el ámbito político, y el presente artículo se inscribe dentro del mismo. Autores como Bayart, Geschiere y Nyamnjoh, 2001; Saugestad, 2001; Kuper, 2003 y el sugerente diálogo llevado a cabo entre Irène Bellier (2011b; 2011c) y Peter Geshiere (2011a; 2011b) en la sección de debate de la revista Social Anthropology de la Asociación Europea de Antropólogos Sociales son un buen ejemplo de ello. Los dos Decenios Internacionales de las Poblaciones Indígenas del Mundo (1995 a 2004;
} 
y América - han sufrido la opresión colonial blanca y su tecnología de explotación/ dominación; ambos han sido geográficamente y políticamente construidos desde el poder imperial europeo y, sin embargo, solo a los pueblos autóctonos de las Américas se les reconoce actualmente como indígenas, cuestionando dicho status a gran parte de las comunidades africanas. Resulta todavía más sorprendente en tanto en cuanto los cinco idiomas de las fuerzas colonizadoras que actuaron sobre el continente africano eligieron el término indígena para designar a los pueblos originarios ${ }^{4}$. A lo anteriormente expuesto, y como colofón de esta gran paradoja, tenemos que añadir el contexto político-históricos en el que surgió la antropología como disciplina académica y el rol que jugaron los indígenas africanos como objeto de estudio en el proceso de consolidación institucional "científica". A pesar de ser protagonistas insignes, especialmente en el nacimiento de la antropología aplicada británica, irónicamente en el siglo XX-XXI se les negará su derecho a reclamar la condición indígena de la que les invistió en sus primeros pasos la "sierva del colonialismo", tal y como ha denominado Talad Asad a la antropología (Asad, 1973: 14).

En este artículo me propongo explorar todas estas contradicciones en las que caen buena parte de la academia europea de origen latino y actor@s polític@s $\mathrm{s}^{5}$ que tan solo reconocen la identidad indígena a aquellos pueblos originarios de las Américas. Mi objetivo es desvelar la ideología de la representación ${ }^{6}$ que se esconde tras dichas aseveraciones; es decir, analizar el poder de denominación a través de la construcción del conocimiento como una de las herramientas más potentes que ha sido utilizada por el aparato imperial a la hora de representar alOtr@ diferente cultural. Desmontar la estructura de significados que contiene esta afirmación resulta especialmente urgente en el contexto actual donde la identidad indígena ha resurgido como una identidad de la resistencia política en el ámbito global y, como no, en buena parte de África. La proclamación de los dos Decenios Internacionales de los Pueblos Indígenas, 1995-2004 y 2005-2014, y la aprobación de la Declaración de los Derechos de los Pueblos Indígenas en el año 2007 por parte de la Asamblea General de Naciones Unidas, ha convertido al espacio internacional en protagonista de primer orden de este nuevo hecho institucional (Searle, 1997)?

2005 a 2014) y la Declaración de los Derechos de los Pueblos Indígenas por parte de la Asamblea General de Naciones Unidas (2007) esta suponiendo un cambio considerable en la manera de entender el significado de Pueblo Indígena, a este respecto recomiendo el capítulo de Irène Bellier (2011a) "La revitalización de los pueblos indígenas en la globalización", así como mi tesis doctoral "Investigando al otro diferente cultural. Un modelo metodológico no etnocéntrico. El estudio de caso: La identidad de las Mujeres Indígenas en los organismos internacionales" (Juanena, 2010).

4 Españoles, portugueses, franceses, ingleses y alemanes.

$5 \quad$ El uso de la@ @o es tan solo un posicionamiento contra el androcentrismo en el lenguaje, entraña un manera de leer más allá de la división dual del género en nuestro idioma, entre masculino y femenino; con mayor importancia cuando hablamos de otras culturas cuya división sexual y roles sociales son tan diversos como lenguajes hay en el mundo.

6 Woolgar (1991) se refiere a este término criticando a aquellas disciplinas que, a pesar de criticar a la ciencia, comparten la misma o muy parecida posición epistemológica ya que tienen "un conjunto de creencias y prácticas que provienen de la idea de que los objetos (significados, motivos, cosas) son la base o preexisten a los signos superficiales (documentos, indicios) que les dan lugar" (Woolgar, 1991: 151). Aplico aquí este término en un sentido más amplio del usado por Woolgar ampliándolo no solo a la ciencia sino a todo el aparato de representación imperial.

7 Utilizó este término según la definición que le da Jonh Searle en su obra La construcción de la Realidad Social (1997). 
A fin de alcanzar el propósito anteriormente expuesto, haré uso de los diferentes conceptos, teorías y análisis de autor@s que abordan la crítica postcolonial y decolonial $^{8}$, realizando un análisis histórico comparativo con la finalidad de deconstruir los procesos que han conducido al actual patrón del poder capitalista a manifestar la ausencia de indígenas en África, perpetuando con ello lo que muy acertadamente ha denominado Antonio Quijano (2000) la colonialidad del poder. Posteriormente, me centraré en un hecho institucional concreto del continente africano: el caso de estudio del pueblo indígena Bubi, originario de la isla de Bioko, el cual comparece ante los organismos internacionales como indigenas y reclama sus derechos inherentes. A modo de conclusión, señalaré algunos de los rasgos que caracterizan a esta "nueva" identidad subalterna africana denominada indigena y el lugar que ocupa actualmente en la arena transnacional.

Este trabajo esta basado en el la observación participante que llevo realizando en el Foro Permanente de Cuestiones Indígenas (ONU-Nueva York) desde el año 2005 y en el Mecanismo de Expertos sobre los Derechos de los Pueblos Indígenas de Naciones (ONU-Ginebra) desde el año 20089 ${ }^{9}$. Por otro lado, el caso descriptivo está fundamentado en el Análisis Crítico del Discurso ACD de las declaraciones del Pueblo Bubi, el cual sigo desde su primera aparición en la arena internacional como pueblo indígena, además de una entrevista en profundidad efectuada en Madrid a una de sus líderes, así como la revisión de abundante bibliografía sobre el tema.

\section{Re-conceptualizando la realidad: el contexto conceptual}

Si la función principal de la teoría es "conceptualizar la realidad", como nos dice el famoso libro sobre investigación social de Ezequiel Ander-Egg (Ander-Egg, 1992), es decir, una forma de "expresar la realidad", se hace del todo imprescindible explicar y a-prehender del marco socio-histórico-teórico donde esa expresión de la realidad se ha formulado. En el caso que nos atañe esta labor es ciertamente relevante, puesto que ambicionamos derrumbar las representaciones que durante más de 500 años han sido construidas alrededor del término indígena. A pesar de que esta voz existía anteriormente al encuentro, o mejor dicho, desencuentro colonial entre Europa y América, es a partir de ese instante que se la dota de los significados modernos que perduran hasta hoy en día, por lo que nuestro examen partirá de ese momento histórico en adelante.

Con el ánimo de ayudar a la compresión de los diferentes factores que han colaborado en la construcción de la paradoja que intento resolver y para la mejor disquisición sobre los mismos, voy a estructurar el discurso en tres hilos narrativos. Estos tres hilos narrativos coinciden con el devenir de la historia y su objetivo es mostrar las implicaciones que han tenido las distintas maneras en las que los imperios europeos, con especial énfasis en los de origen latino, han nombrado alOtr@ colonizad@, tanto en América como en África.

\footnotetext{
8 Aunque los autores decoloniales latinoamericanos marcan cierta distancia respecto a sus colegas postcoloniales con orígenes anglosajones, considero que ambas corrientes tienen como objetivo el proyecto descolonizador por lo que en este trabajo no haré distinción ninguna.

9 Creado en el año 2007 por el Consejo de Derechos Humanos.
} 
Comenzaré analizando los términos que les otorgaron los colonizadores a los Otr@s colonizad@s en el primer contacto del “encuentro colonial”. Seguidamente, examinaré de que manera han afectado los diferentes modelos de administración colonial a la hora de nombrar a la otredad colonizada: dos Europas, dos continentes, dos momentos históricos. Por último, exploraré los efectos que han causado los procesos de independencia en la construcción de las nuevas identidades devaluadas ${ }^{10}$. A lo largo de todo el camino nos acompañara la tesis de Aníbal Quijano y de otros autores post- y de-coloniales.

Antes de comenzar me gustaría señalar que estas tres causas históricas no son las únicas que han influido en el reconocimiento actual de la existencia de los indigenas en Africa; factores de coyuntura política en cada caso particular tienen un peso directo sobre la cuestión. Sin embargo, en este artículo me he querido centrar en la transcendencia que han tenido los hechos históricos en la construcción del imaginario occidental actual que pesa sobre la identidad indigena africana.

\subsection{Introito}

Las condiciones socioculturales en las que se construyó a ese Otr@indígena fue el "sistema-mundo moderno/colonial" que nos relata Walter D. Mignolo (Mignolo, 2000). En él se han producido y reproducido la colonialidad del poder, al decir de Aníbal Quijano, creando nuevas identidades históricas y sociales — blancos, indios, negros, mestizos, aceitunados - que, combinado con una distribución racista del trabajo y de las formas de explotación del capitalismo colonial/moderno, articuló una nueva hegemonía eurocentrada basada en identidades naturalizadas (Quijano, 2000). Me detendré a analizar detalladamente la idea de colonialidad del poder de Aníbal Quijano ya que, a pesar de que comparto la esencia de este concepto, difiero en algunos matices importantes que afloran cuando lo aplicamos al caso africano.

Aníbal Quijano distingue entre colonialismo y colonialidad. Según este autor, colonialismos ha habido muchos mas colonialidad, entendida como un patrón de poder, solo una: aquella que nació con la constitución de América y llega hasta nuestros días expresado en lo que solemos denominar globalización. En palabras suyas:

La colonialidad es uno de los elementos constitutivos y específicos del patrón mundial de poder capitalista. Se funda en la imposición de una clasificación racial/étnica de la población del mundo como piedra angular de dicho patrón de poder y opera en cada uno de los planos, ámbitos y dimensiones, materiales y subjetivas, de la existencia social cotidiana y a escala societal. "Se origina y mundializa a partir de América""1.

... con América (Latina) el capitalismo se hace mundial, eurocentrado y la colonialidad y la modernidad se instalan asociadas como los ejes constitutivos de su "específico patrón de poder"'12.

(Quijano, 2000: 342)

10 Esto no significa que dichas causas existan independientemente unas de otras, su articulación es evidente, sino que las expongo discriminadamente para facilitar la comprensión de una realidad articulada, compleja y contradictoria.

11 Las comillas son mías.

12 Las comillas son mías. 
Este "específico patrón de poder" originado durante el colonialismo como sistema político formal, es una estructura que perpetúa la situación de dominación creada bajo la relación colonial. El patrón de poder hegemónico actual, que se desarrolla en el marco del sistema-mundo wallersteniano, se estableció sobre dos ejes fundamentales, a saber:

1)... la clasificación social de la población mundial sobre la idea de raza, una construcción mental que expresa la experiencia básica de la dominación colonial... 2) De otra parte, la articulación de todas las formas históricas de control del trabajo, de sus recursos y de sus productos, en torno del capital y del mercado mundial.

(Quijano, 2000: 246) ${ }^{13}$

Particularmente interesante para nosotros es el análisis que realiza Quijano de ese "eje fundamental" que es la idea de raza. Una categoría mental moderna, por la que se codifican las diferencias fenotípicas entre conquistadores y conquistados y terminan produciendo identidades históricamente nuevas, entre otras: indios y negros. Estas nuevas identidades fueron asociadas a las jerarquías del patrón de dominación colonial, es decir: raza e identidad racial fueron establecidas como instrumentos de clasificación social básica de la población (Quijano, 2000: 246-247). Sin embargo, nos encontramos ante una importante paradoja: si bien es cierto que los pueblos originarios de estos dos continentes fueron nombrados de diferente manera al comienzo de la colonización americana — negros e indios - lo que provocó dos hechos institucionales singulares; no menos cierto es que, tanto en las administraciones burocráticas de las colonias americanas del siglo XV como en los gobiernos coloniales africanos del siglo XIX y XX se utilizara el mismo término para nombrar al Otr@ colonizad@: indígena. Como veremos más adelante, esta cuestión va más allá de un mero asunto nominal y ha tenido importantísimas consecuencias sobre la realidad actual.

El segundo eje del que nos habla Quijano, ese "patrón global de control del trabajo, de sus recursos y de sus productos" por el que se establece una "nueva, original y singular estructura de relaciones de producción en la experiencia histórica del mundo: el capitalismo mundial" (Quijano, 2000: 247), se asentó en buena parte sobre la base de estos dos hechos institucionales: indígenas siervos = americanos; negros esclavos = africanos en la colonización primigenia americana. Sin embargo siglos más tarde, cuando se produce la colonización del continente africano bajo una Europa que inicia y logra su desarrollo industrial, se denominará también indígena al ejército africano de mano de obra forzosa que se incorporará a su proyecto imperial. Una misma denominación burocrática realizada en diferentes momentos de la historia tendrá como resultado distintas realidades políticas contemporáneas.

\subsection{Dos formas diferentes de nombrar al Otr@ en el primer momento del "encuentro colonial"}

Reza el dicho: "Quien domina denomina" y tras las diferentes formas de denominar se ocultan siglos de tecnología de dominación, por ello vamos a iniciar nuestro discurso desde el primer instante en el que se comenzaron a construir los significados

13 La numeración es mía. 
modernos de las identidades indigenas y negros. Siguiendo a Quijano, este momento se produce cuando se crea la primera identidad geocultural moderna y mundial llamada América ${ }^{14}$ (Quijano, 2000). Junto a ella, se concibe a su vez la primera identidad acerca del sujeto colonizado: la identidad indigena. Más adelante los negros ${ }^{15}$, aquellos africanos traídos a las Américas para trabajar como mano de obra esclava, se convertirán en la segunda identidad moderna dada a los sujetos colonizad@s. Hasta aquí comparto la tesis quijaniana y su potente concepto de la colonialidad del poder, mas difiero del autor en la exclusividad que concede a América como el único lugar desde el que se origina y mundializa la citada colonialidad del poder. África, al igual que América, participó en el origen y en la mundialización del patrón mundial del poder capitalista. El "descubrimiento moderno"16 de ambos continentes por parte de Europa se produce a la par, ambos son utilizados simultáneamente en el nuevo sistema mundo en el que se constituye el comercio triangular; si bien es cierto que jugarán diferentes roles desde sus lugares periféricos.

Mayor reflexión merecen los argumentos discursivos de los que se sirvió el poder colonial a la hora de diferenciar las dos categorías raciales sobre las que se basó la colonialidad del poder, y a los que Aníbal Quijano no parece conferirles relevancia alguna. Aludo aquí a la defensa - teológica, jurídica y filosófica - acerca de la capacidad de los nativos de poseer razón y alma, facultad que les fue reconocida a los autóctonos americanos y negada a los nativos africanos en un momento en el que la esclavitud de los negros africanos se encontraba ya establecida en el "nuevo continente", allá por el siglo XVI (Rivera, 1992: 13). La famosa apología de Bartolomé de las Casas a favor de la libertad de los indios americanos dejó al margen al esclavo negro africano ${ }^{17}$; en ningún momento la iglesia católica tuvo como política la defensa de la libertad de los esclavos negros ${ }^{18}$. Ello permitió su deshumanización, más si cabe, respecto al siervo indígena americano y, sobre todo, concedió alas al mayor éxodo sangriento de la historia de la humanidad: la trata atlántica.

Pocos años antes de que Colón arribase a la costa americana, el portugués Enrique el Navegante desembarca en las costas africanas en busca de oro y esclavos. Los viajes que los portugueses realizaron durante la "era de los descubrimientos" - siglos XV-XVII- no solo sirvieron para ampliar los conocimientos europeos acerca de África; sino que también iniciaron un proceso que transformaría el pensamiento europeo sobre los africanos, al igual que ocurrió con los americanos ${ }^{19}$. El contexto de esta transformación acerca de la imagen sobre los africanos fue el comercio transatlántico de esclavos. La esclavitud había sido un rasgo prominente

14 Siguiendo a Quijano: "Europa fue la segunda y fue constituida como consecuencia de América, no a la inversa" (Quijano, 2000).

15 Esto no quiere decir que no se utilizase la palabra negro anteriormente, al igual que la de indígena, sino que no tendría las connotaciones que se le comenzó a dar a partir de entonces.

16 Entrecomillo las palabras "descubrimiento moderno" para resaltar que los territorios que se conocen actualmente como América y África ya estaban "descubiertos" por otras sociedades antes de que los europeos hicieran acto de presencia. La "modernidad" del descubrimiento alude a su llegada y a su manera particular de "descubrir".

17 Rivera (1999) señala que si bien Las Casas sí dedicó algunas líneas a la denuncia de la situación de los negros africanos en América y a defender su libertad, fueron éstas escasas y con mucha discreción (Rivera, 1992: 14).

18 Esto se puede comprobar en las diversas bulas y decretos papales de los siglos XV-XVI en contra de la esclavitud de los nativos americanos y a favor de los nativos africanos (Rivera, 1992: 15).

19 África, al igual que América, es "descubierta" por Europa. Las relaciones entre África y Europa existían anteriormente pero en ellas no se daba todavía la colonialidad del poder. No eran relaciones "modernas", tal y como más tarde las construyó Europa. 
de la cultura mediterránea clásica y continuó de diversas formas en la Europa medieval. Asimismo existió en el mundo musulmán, incluyendo el norte África y en África subsahariana. Sin embargo, fue el comercio atlántico de esclavos durante los siglos XV-XIX, causante de la migración forzada de 12 millones de africanos a las Américas el que forjó un vínculo explícito en las mentes europeas entre inferioridad racial, esclavitud, negritud y África. La idea moderna de África surgió, en muchos aspectos, desde el crisol de deshumanización de la esclavitud atlántica y esta fue más allá de lo que Quijano apunta acerca de la indigenidad americana. Esta diferencia entre negritud africana e indigenidad americana se creó y se perpetuó institucionalmente hasta el inicio de la penetración del continente africano por parte de los europeos, a finales del siglo XIX y principios del siglo XX. A partir de ese momento, la colonización efectiva de las tierras africanas hizo necesaria la abolición de la esclavitud y el final formal de la trata atlántica ${ }^{20}$, lo que dejó paso a la explotación del trabajo forzoso en el continente negro. África pasó de ser un continente productor de esclavos a un territorio donde se impuso un modo de producción cuasi-esclavista. "Lo negro" se convirtió en indígena.Cierto es que Quijano nos señala que la corona de Castilla decidió desde muy temprano el cese de la esclavitud de los indios, según argumenta "para prevenir su total exterminio" (Quijano, 2000: 249) ${ }^{21}$, lo que les permitió el paso de la esclavitud a la servidumbre ${ }^{22}$. Sin embargo, no concede ninguna importancia al argumento discursivo que contribuyó, desde los inicios, al imaginario colectivo que desde ese momento en adelante comenzó a construirse sobre estas dos identidades subalternas delOtr@ colonizad@: indígena y negro. Para el tema que nos ocupa considero especialmente relevantes los razonamientos que sirvieron para diferenciar entre esclavo negro africano y siervo indígena americano, ya que fueron los que consiguieron dar la textura - aquello que da cohesión al texto- necesaria al discurso que sostuvo la ideología de la representación que impuso el poder colonial en el surgimiento del modo de producción capitalista. Estos argumentos, que marcaron las fronteras entre estas dos identidades modernas, fueron la base sobre la que se construyeron los pre-juicios que perduran en el imaginario colectivo europeo, especialmente el latino. Actualmente, en muchos de los discursos podemos escuchar el eco que retumba entre aquellos muros que levantó el patrón mundial del poder colonial entre estas dos categorías raciales: indígenas versus negros.

Un detalle de menor relevancia, pero no por ello menos curioso, es la aseveración incorrecta de Quijano al afirmar que "solo los españoles y los portugueses, como raza dominante, podían recibir salario, ser comerciantes independientes, artesanos independientes o agricultores independientes, en suma, productores independientes de mercancías" (Quijano, 2000: 249). En África, ciertas élites nativas jugaron un papel que no podemos obviar. Traficantes esclavistas negros africanos comerciaron con esclavistas europeos a cambio de productos manufacturados. Por lo tanto, si bien en América los negros africanos no ejercieron, sin lugar a dudas, como comerciantes

20 La abolición de la esclavitud fue un proceso lento que se resiste a generalizaciones. Respondieron diversos factores y se combinaron de formas distintas de acuerdo con cada caso en particular.

21 Quijano mantiene que: "El vasto genocidio de los indios en las primeras décadas de la colonización no fue causado principalmente por la violencia de la conquista, ni por las enfermedades que los conquistadores portaban, sino porque tales indios fueron usados como mano de obra desechable, forzados a trabajar hasta morir". (Quijano, 2000: 250)

22 Una servidumbre en condiciones de esclavitud en la mayoría de los casos, pero servidumbre al fin y al cabo. 
independientes no podemos decir lo mismo acerca del África de la época, aún no explorada, todavía no colonizada.

Resumiendo: bajo la designación primigenia en el encuentro colonial americano de diferenciar entre indígenas y negros se esconde la necesidad de mantener mano de obra esclava - negros africanos - para la explotación de las colonias americanas, sin la cual no hubiera sido posible. En el mismo tiempo histórico, África es imaginada, por los ibéricos inicialmente y más tarde por el resto de europeos, meramente como una fuente de recursos, sobre todo un vivero de mano de obra esclava. La situación subalterna de la identidad africana superó en tiempo y en condición a la categoría indígena dada a los autócton@s american@s. África, como identidad geocultural moderna, se construyó desde el mayor desprecio a la condición humana; una estructura mental que dejaría una huella indeleble en el imaginario occidental.

A partir del siglo XIX, cuando comienza la penetración del continente africano y su consecuente ocupación efectiva, las administraciones coloniales nombrarán indígenas a todos aquellos sujetos colonizados originarios del territorio. Sin embargo, ya llevaban los africanos siglos de negritud en el continente americano y en las costas de su continente.

\subsection{La importancia del modelo de administración colonial y sus efectos a la hora de nombrar la otredad colonizada. Dos continentes: África y América; dos Europas: Ibérica y Europa occidental}

Si bien los exploradores europeos, más precisamente los ibéricos, recalan en las costas africanas y americanas alrededor de la misma década; la penetración en el contienen africano se produce bastante más tarde, no pudiendo hablar de la colonización del continente hasta bien entrado el siglo XIX, - la Conferencia de Berlín se reúne en 1884-1885-. Por entonces, las Américas ya cargaban sobre sus espaldas casi cuatro siglos de administración colonial, no así el continente africano ${ }^{23}$. La Europa que se reparte África es una Europa muy distinta a la Europa pre-moderna ibérica de la primera colonización americana; pese a que el capitalismo mundial fue desde sus inicios colonial/moderno y eurocentrado, tal y como defienden los autores del moderno sistema-mundo (Wallerstein, 2005).

Al decir de Quijano, con la creación de América se crea la segunda id-entidad geocultural llamada Europa, una región históricamente nueva que emerge "como la sede central del control del mercado mundial" aunque a su vez reconoce que "en el mismo movimiento histórico se producía también el desplazamiento de la hegemonía desde las costas del Mediterráneo y desde las costas ibéricas, hacia las del Atlántico Noroccidental" (Quijano, 2000: 249). Dos Europas distintas, geográfica y temporalmente hablando, dominan al Otr@ colonizad@ denominándole. Ambas utilizan un solo término en sus administraciones coloniales: indígena. No obstante, y a pesar de la coincidencia en el uso de un mismo significante, el imaginario construido sobre el significado difiere notablemente. La Europa mediterránea del primer encuentro colonial con América es una Europa agrícola, donde prima más la racionalidad tradicional y/o carismática weberiana en su lógica colonizadora; muy lejos de la racionalidad moderna de finales del siglo XIX y del siglo XX. No solo por el mayor

23 Durante ese tiempo África sufrió la sangría de la trata atlántica pero no podemos hablar de administración colonial hasta el siglo XIX-XX. 
peso de la iglesia, sino esencialmente por la menor importancia y desarrollo del dispositivo ${ }^{24}$ burocrático de dominación que se impuso en la administración de las colonias. Por el contrario, la Europa colonizadora de África es la Europa de la revolución industrial plenamente moderna, cuya lógica legal formal patriarcal y heterosexual burocrática estará completamente desarrollada ${ }^{25}$. Esta última singularidad es particularmente importante, especialmente a la hora de crear lo que Quijano llama una "nueva intersubjetividad mundial" como parte de ese "patrón del poder mundial" (Quijano 2000: 251). Si bien es cierto que "con América se inicia, pues, un entero universo de nuevas relaciones materiales e intersubjetivas" (Quijano 2000: 255) ${ }^{26}$, considero que esta nueva "intersubjetividad" no se desarrollará plenamente hasta la evolución de ese modo de racionalización típicamente occidental que Max Weber describió en su obra La ética protestante y el espíritu del capitalismo (1904-1905). La aplicación de la lógica instrumental legal formal weberiana que rige el nuevo centro de poder hegemónico constituido en Europa occidental será la que gobierne y ayude a "el control de todas las formas de control de la subjetividad, de la cultura, y en especial del conocimiento, de la producción del conocimiento." (Quijano, 2000: 250) y se aplicará en todo su esplendor durante la colonización africana.

Recordemos: de los cuatro tipos ideales de acción social que nos propone Weber y sus modos de dominación tan solo la racionalidad legal formal se dio en occidente con la industrialización. La racionalización legal formal implica el cálculo de medios y fines y se presenta bajo reglas, leyes y regulaciones universalmente aplicadas fundadas, sobre todo, en las instituciones económicas, legales y científicas, así como en las formas burocráticas de dominación. Esta fue la racionalidad que predominó en la administración europea occidental, la que ha dominado en la academia y la que engendró y gobierna el capitalismo actual ${ }^{27}$. Las modernas disciplinas científicas nacidas al calor de la nueva racionalidad originada colaborarán en la construcción del poder imperial y el dominio sobre las Otras culturas armando de argumentos al epistemicidio que llevarán a cabo. Papel importantísimo jugó la antropología, producto de esta particular forma de racionalización que contribuyó en la construcción de la ideología de la representación acerca de ese Otr@ colonizad@.Junto con las otras "ciencias" que la apoyaron, la antropología ocupó el lugar epistémico de enunciación del poder colonial ${ }^{28}$ que bajo su razón universal creó la ficción reguladora de lo humano/animal, masculino/femenino, el aquí/allí, lo racional/irracional y muchas otras representaciones de su sistema-mundo moderno/colonial, incluida esa alteridad no racional que denominó indígena o negro. Relegó a los sujetos categorizados

24 Aquí utilizo el término dispositivo en el sentido foucaultiano del término.

25 La brutalidad y violencia de la invasión de territorio es común a las “dos Europas”. Inclusive, en ambos procesos imperialistas se dan las 3 lógicas de dominación weberianas. No obstante, el desarrollo del poder instrumental legal formal que se alcanzó en el siglo XIX-XX está muy alejado del que practicaba la península ibérica durante los siglos XV-XVI-XVII y XVIII que según la teoría weberiana sería inexistente.

26 Considero que el análisis que realiza Quijano acerca de cómo la modernidad y la racionalidad fueron imaginadas como productos europeos deja mucho que desear. Mucho más detallado y acertado me parece el que elabora Max Weber en la Ética y el espíritu del capitalismo.

27 Sin embargo, no hay que olvidar que Weber pensaba que en la realidad social tanto las formas de dominación como los tipos de racionalidad no se daban de una forma pura sino que se encontraban elementos de una u otra aunque fuese una la que dominase. Weber nos está hablando de tipos ideales que son modelos o del tipo de acción social que domina una sociedad. Aún así, la racionalidad legal formal sólo fue posible encontrarla en Occidente y a la par del nacimiento del capitalismo moderno.

28 Entiendo por lugar epistémico de enunciación del poder colonial como el espacio donde se crea y se expresa el saber del poder colonial. Su lugar de enunciación. 
como tales al rincón de lo primitivo, lo salvaje y lo bárbaro, invalidándolos como sujetos gnoseológicos. En ocasiones, la antropología fue más allá y colaboró con los gobiernos coloniales. Concretamente la antropología aplicada, en su proceso de consolidación como disciplina científica, recibió el apoyo del gobierno británico por el servicio que le prestaba en las colonias de ultramar (Asad Talad, 1973) ${ }^{29}$. Desde la India hasta África, la antropología sirvió al poder para "resolver los problemas" a los que las sociedades indígenas se veían afectadas por las nuevas influencias debidas al encuentro colonial moderno (Goldschmidt, 1968). Ahora bien, como disciplina universitaria la antropología no consolida su status hasta la Segunda Guerra Mundial; mas eso no fue un obstáculo que le impidiese participar en la creación de las reglas de representación imperial acerca delOtr@indigena african@. Al imaginario construido sobre la otredad devaluada indígena american@ se le suma el peso delsersubdesarrollad@ de la era industrial,más primitiv@ si cabe en la escala de la evolución occidental (Juanena, 2010).

Esa típica racionalidad legal formal weberiana también estuvo presente en todos los ámbitos de las nuevas administraciones coloniales. Gobiernos directos franceses y gobiernos indirectos británicos nombraron igualmente indígenas al Otr@ african@ colonizad@. Todas las autoridades coloniales plenamente capitalistas del siglo XIX y XX hicieron uso de la dominación legal formal para ejercer su gobierno, lo cual provocó cambios estructurales en las sociedades africanas. Tanto la creación de "líderes tribales" locales (Hobsbawn y Ranger, 2002) como las migraciones forzosas internas que se realizaron allí donde no había suficiente mano de obra para explotar los recursos de una Europa codiciosa de riquezas, alteraron por completo la vida comunitaria. Las autoridades coloniales se sirvieron de las leyes consuetudinarias para aplicar la política nativa (Campos, 2004, 2005), lo que convirtió a su ingeniería social en un verdadero ejemplo de la racionalidad weberiana típicamente occidental; en más de una ocasión, con la ayuda de la antropología aplicada. No solo se crearon grupos étnicos o líderes políticos sino que se quebró la unión entre autoridad y poder que poseían los tradicionales líderes africanos. Estos "nuevos líderes tradicionales" escogidos por el gobierno colonial adquirirán un poder hasta entonces inexistente, mientras que la autoridad local seguirá ejercida por los líderes religiosos u otros ${ }^{30}$. Esta desvinculación entre poder y autoridad irá in crescendo con consecuencias difíciles de presagiar en el África contemporánea. Patrick Chabal, escribiendo acerca de la politica del ser en África nos habla de la necesidad que comienzan a sentir los políticos "modernos" de abastecerse de autoridad "tradicional" para satisfacer las demandas del mundo "tradicional" al que también pertenecen los propios líderes políticos (Chabal, 2011: 65-68).

Concluyendo: Una Europa occidental que comienza su revolución industrial crea y aplica una tecnología de la dominación - el aparato burocrático racional legal

29 Un buen ejemplo de ello fue el caso del famoso antropólogo Evans-Pritchard quien escribió sobre los Azande y Nuer del sur de Sudán además de promocionar la etnografía y los trabajos de campo en África como miembro del Colonial Social Science Research Council. Durante la Segunda Guerra Mundial Evans-Pritchard prestó sus servicios en las plazas militares de Etiopía, Libia, Sudan y Siria.

30 No quiero decir con esto que anteriormente a la colonización europea la organización política de las sociedades africanas estuviera solamente en manos de líderes tribales; ni mucho menos. El poder político como concepto social alcanza sutilezas difíciles de medir y las sociedades africanas presentan un mapa tan diverso como amplio es su territorio. Solo quiero poner de manifiesto la desestructuración que produjo la administración colonial en la organización social "tradicional" de las comunidades africanas y los cambios relacionados con la autoridad y el poder. 
formal - más compleja y sofisticada que la construida por la Europa ibérica, agrícola y bastante a la zaga de la modernidad del norte. La representación de ese Otr@ indígena colonizad@ de ambas Europas difiere considerablemente, hasta el punto de negar esta condición al african@ por agravio comparativo con esa "primera" imagen creada bajo la colonización de la Europa mediterránea de "lo indígena" en América.

A esta sutil diferencia, que no incorpora Quijano en su análisis, entre las dos Europas - agrícola e industrial — podríamos añadir los efectos que han tenido y tienen sobre el reconocimiento de la identidad indígena africana, según fuese o fuera aplicada esa dominación racional legal formal a los diferentes modelos de administración colonial europeos. Los denominados gobiernos indirectos o gobiernos directos y sus variaciones, dificultaron o facilitaron la prevalencia de una identidad indígena africana hasta la actualidad, lo cual supondría un mayor o menor obstáculo en el camino hacia el reconocimiento de su identidad política. La variabilidad de los casos y las particularidades históricas de los mismos dificulta la elaboración de una proposición universal sobre esta cuestión, que además excede el objetivo de este artículo ${ }^{31}$.

\subsection{Los procesos de independencia ${ }^{32}$ y la re-construcción de las identidades postcoloniales}

Llegamos al tercer hilo narrativo: de qué forma han influido sobre las nuevas identidades subalternas contemporáneas la manera en la que fueron nombrados y se nombraron a sí mismos los sujetos coloniales durante los procesos independentistas.

Los líderes que participaron en la creación de los nuevos Estados-Nación y sus discursos nacionalistas han tenido una influencia notable en la construcción de las identidades que actualmente son reivindicadas por los colectivos que habitan dentro de las fronteras gubernamentales contemporáneas. Mientras en el continente americano fueron las élites blancas, los propios colonos principalmente, quienes dirigieron los proceso de independencia de las metrópolis, en África serán las élites africanas — aunque las occidentalizadas ${ }^{33}$ — quienes liderarán dicho proceso. Como consecuencia de esto, las elites blancas independentistas americanas tuvieron la necesidad de conservar en su discurso nacionalista la distinción entre un

31 Sin embargo, resulta curioso comprobar que la mayoría de los pueblos indígenas africanos que estuvieron bajo un gobierno colonial británico sean los que, hoy en día, tienden a tener menos dificultades en el reconocimiento de su identidad indígena. Tal es el caso de los Maasais (Kenia, Tanzania), Ogiek, Samburu, Turkana, (Kenia), Cushite, Nio-Hamite, San (Tanzania), Himba (Namibia) o Khoekhoe (Sudáfrica). No obstante, las formas de dominación colonial fueron más complejas que la simple clasificación al uso que suele establecerse entre gobierno directo o gobierno indirecto al igual que existen, aunque menos, casos de indígenas reconocidos que estuvieron bajo la administración francesa. Se hace obligatorio el estudio específico de cada caso, aquí tan solo deseo señalar que es necesario el análisis histórico de la administración colonial para comprender en mayor medida las actitudes ante el reconocimiento actual de las identidades indígenas en África.

32 Hablo concretamente de los procesos de independencia y la creación de los Estado-Nación. Intencionadamente no utilizo el termino descolonización ya que como proceso lo considero inacabado.

33 Aquí me refiero al concepto de occidentalizado según lo define Ferrán Iniesta. Occidentalizados o nueva clase occidentalizada hace referencia al grupo social africano aculturado, conocedor de las lenguas de los colonizadores y preparado para las tareas propias de la administración o de la gestión económica. Introducidos en la lógica y comportamientos occidentales, este grupo social fue una necesidad del colonizador que contó con la colaboración de sectores africanos que vieron en su aproximación al poder europeo la posibilidad de mejorar sus posiciones sociales. De aquí salieron conformistas y contestatarios pero para todos el nacionalismo sería la expresión teórica de los occidentalizados (Iniesta, 1998). 
nosotros ${ }^{34}$ blanco y diferenciado frente a unell@s indigena; un ell@s indigena utilizado como símbolo nacional aunque no incluido en el proyecto emancipador. En el caso africano, el nosotros de la élite independentista africana es construido por el negro africano occidentalizado ${ }^{35}$ donde no hay lugar para un nosotros distinto alell@s indígena. "En África tod@s somos indígenas" declararán las élites de los nuevos gobiernos nacionales.

Durante los años 50 y 60 la mayoría de los países africanos consiguen la independencia y con ella se produce un nuevo cambio en la organización política interna de las sociedades africanas. El poder político, que bajo el gobierno colonial hasta ese momento había sido ejercido por los "líderes tribales" coloniales, es sustituido por los modernos líderes burgueses nacionalistas, los llamados occidentalizados. Contestatarios o conformistas, esta élite negra será educada bajo el modelo hegemónico eurocéntrico racional moderno y supondrá un giro cualitativo transcendental a la hora de interpretar el poder en la "nuevas" sociedades nacionales africanas. Como he señalado más arriba, la brecha hendida bajo el colonialismo entre autoridad y poder se expande con la creación de los Estados-Nación, con consecuencias complejas e impredecibles en el África contemporánea.

Con los procesos de independencia, se produce la reconversión o, más frecuentemente, la aparición de líderes políticos nacionalistas en el nuevo panorama gubernamental de las sociedades africanas. Educados muchos de ellos en las universidades occidentales, esta nueva élite social - los occidentalizados - lideraron las luchas por la independencia en África. Con el paso del tiempo y tras las independencias de los nuevos Estados-Nación, el indigenismo se convirtió en un instrumento al servicio de la nueva identidad nacional y una herramienta de destrucción de las diversas identidades locales para integrarlas en el todo homogéneo nacional. Fue un elemento significativo que ayudó en la construcción de las nuevas comunidades imaginadas. Esto es lo que algunos han denominado "Indigenismo de Estado" (Korsbaek y Sámano, 2007). Ese mismo "Indigenismo de Estado" será lo que lleve a la mayoría de Estados africanos actuales a NO reconocer Pueblos Indígenas en sus territorios bajo el enunciado "todos somos indígenas en África". Serán las élites masculinas educadas por occidente las que lideren ese discurso integracionista nacional, mientras que millones de subaltern@s continuaran con su resistencia silenciosa. Sus voces permanecen acalladas hasta el encuentro con nuevos espacios reivindicativos transnacionales en los que puedan de nuevo alzar su voz. Los años de opresión por los antiguos y, ahora, nuevos poderes económicos, políticos y culturales, unidos a la desilusión de las grandes narrativas de la modernidad, tales como el marxismo y/o el nacionalismo, que protagonizaron la primera lucha anticolonial fueron cuajando en la conciencia social de1@s nativ@s y han terminado por contribuir al surgimiento de nuevas identidades postcoloniales y a la re-significación de las "viejas" adormecidas o manipuladas hasta ese momento. Un cambio cualitativo se ha producido en el significado de la identidad, en el significado de ser indígena. La historia colonial y los procesos de independencia de los nuevos Estados jugarán un papel transcendental en el reconocimiento de este sujeto colectivo denominado indígena en los que algunos

34 En esta ocasión no escribo con@ el sustantivo porque en ambos casos, África y América, los proyectos independentistas fueron patriarcalistas. Cierto es que el proyecto independentista africano fue más inclusivo, respecto al género, que el americano.

35 Excepción africana es el caso de Sudáfrica que se independizó de Inglaterra como colonia blanca. 
autor@s han llamado la Segunda Ola de la Indigenidad (Second-wave indigeneity) (Venkateswar, Hughes, Kidd et al., 2011: 1).

\section{El caso de estudio: la comunidad bubi ubicada en la isla de Bioko}

El Pueblo Bubi de la isla de Bioko es uno más de los tantos casos de comunidades indígenas africanas que han desplazado su lucha política a los espacios transnacionales en los últimos años, presentándose ante los mismos como pueblo indígena y reclamando sus derechos inherentes. Esto ha provocado un fuerte debate, tanto en la academia como en los espacios políticos, acerca de la "autenticidad" y legitimidad sobre su condición indígena. Al igual que otras comunidades indígenas africanas, colisionan contra el imaginario colectivo europeo - sobre todo latino - acerca del deber ser de lo indígena. Hablando de nuevo desde el limbo simbólico en el que se sitúa la colonialidad del poder se mantiene la retórica intransigente y etnocéntrica que impuso las reglas de representación sobre elOtr@ diferente cultural. De-construir esa narración política acerca de "lo indígena" en África es el objetivo fundamental de este artículo y el caso de estudio descriptivo escogido cumple con dos valiosas características: por una parte, el primer encuentro colonial en este territorio africano se produce en el mismo intervalo temporal que se crea la id-entidad geocultural llamada América; por otro lado, será la misma id-entidad geocultural colonizadora - la Europa ibérica - la que realice la empresa colonizadora a ambos lados del Atlántico. Y, a pesar de ello, los sujetos colonizados africanos se enfrentan con mayores dificultades en su reconocimiento como colectivo indígena que aquellos de origen americano.

Partiendo del esquema anterior de los tres hilos narrativos en los que se nombra al Otr@ colonizad@, contrastaré el caso descriptivo de la comunidad bubi analizando las condiciones socioculturales y políticas en las que se construyó/destruyó a ese Otr@indígena africano según ha sido nombrado por la colonialidad del poder en el transcurrir de la historia.

\subsection{Dos formas diferentes de nombrar al Otr@ en el primer momento del "encuentro colonial": La isla de Ferñao do Pó}

Etulá, isla conocida hoy con el nombre de Bioko, fue poblada por el pueblo bubé (bubi) alrededor del siglo V según datan las referencias. A sus costas arribaron los exploradores europeos en 1472 bautizando el "nuevo" territorio como Fernão do Pó, en honor al navegante portugués que alcanzó su litoral. Situada en la "costa de los esclavos", frente al Golfo de Guinea, desde los inicios del "encuentro colonial" con Europa fue enclave portuario en la ruta del comercio esclavista, donde operaron holandeses, portugueses, británicos y españoles ${ }^{36}$. L@s historiador@s suelen narrar lo ocurrido en las islas del Golfo de Guinea, sobre todo de Santo Tomé y Príncipe, como un experimento piloto de lo que años más tarde fue el futuro comercio triangular con una base atlántica de plantación. Por lo cual, podemos afirmar que la isla de Etulá ha sido objeto de la explotación del capitalismo colonial/moderno en sus diferentes formas desde el primer momento del desencuentro colonial europeos-

36 La presencia de los británicos supuestamente fue para controlar el tráfico ilegal de esclavos, aunque la isla sirvió para abastecerse de mercancías necesarias en la ruta atlántica. 
africanos. Es un claro ejemplo de que la colonialidad del poder no solo se origina y organiza a partir de América, tal y como defiende Quijano, sino que se produce al mismo tiempo - si no antes - en Africa ${ }^{37}$.

Por la firma de los tratados de San Ildefonso (1777) y el Pardo (1778) España adquiere el territorio insular, los derechos de la trata esclavista y el libre comercio que acaecían en la isla por aquel tiempo. En orden a estos dos convenios, la corona portuguesa y española se reparten y regulan los territorios de ultramar. En el Tratado de San Ildefonso (1777) apenas figura la isla de Fernando Poo; tan solo en los anexos IV y V se reseña en dos ocasiones con el objetivo de formalizar su cese de la corona portuguesa a "Su Majestad Católica" y expresar el deseo de establecer relaciones comerciales en la "mas perfecta armonía", según el compromiso de tratarse mutuamente en sus puertos, "como la Nación mas favorecida", conforme se declara en el documento firmado (Del Cantillo, 1843: 534-544).

Más atención le dedica el acuerdo firmado en El Pardo, en 1778, ajustado entre "el muy poderoso don Carlos III rey de España y de las Indias y la muy poderosa doña María reina de Portugal" según reza en el título. Sus artículos XIII y XV normalizan las relaciones comerciales entre los vasallos de los dos reinos y el tráfico esclavista que se daba en el territorio insular. En estos tratados hace acto de presencia elOtr@african@colonizad@que es nombradocomonegro.

Deseando Sus MAJESTADES CATÓLICA Y FIDELÍSIMA promover las ventajas del comercio de sus respectivos súbditos, las cuales pueden verificarse en el que recíprocamente hicieren de compra y venta de negros $^{38}$, sin ligarse á contratas y asientos perjudiciales, como los que en otro tiempo se hicieron con las con las compañías portuguesa, francesa é inglesa, las cuales fue preciso cortar ó anular, se han convenido los dos altos príncipes contrayentes en que para lograr aquellos y otros fines y compensar de algún modo las cesiones, restituciones y África renuncias hechas por la Corona de España...(...)

Articulo XIII del Tratado del Pardo (1778)

Además de los auxilios que recíprocamente se habrán de dar las dos naciones española y portuguesa en dichas islas de Annobón y Fernando del Po y en las de Santo Tomé y del Príncipe, se han convenido Sus MAJESTADES CATÓLICA Y FIDELÍSIMA en que en las mismas pueda haber entre los súbditos de ambos Soberanos un trafico y comercio franco y libre de negros ${ }^{39}$; y Tráfico de en caso de traerlos la nación portuguesa á las referidas islas de Annobón y de Fernando del Po, serán comprados y pagados pronta y exactamente, con tal que los precios sean convencionales y proporcionados á la calidad de los esclavos, y sin exceso á los que acostumbren suministrar ó suministraren otras nación es en iguales ventas y parajes.

Articulo XV del Tratado del Pardo (1778) citado en Del Cantillo, 1843: 547-542.

37 Se podría pensar que en el caso de Frenando Poo la tesis de Quijano es espacialmente cierta dada las estrechas relaciones que se dieron entre Cuba y la isla (García Cantús, 2004). Sin embargo, cuando se dan dichas relaciones se llevan años de tráfico esclavista y la idea de negro esclavo esta más que consolidada. Por esta razón afirmo que las id-entidades geoculturales África y América surgen al unísono.

38 La cursiva es mía.

39 La cursiva es mía. 
Desde el primer momento del "encuentro colonial" hasta la conquista efectiva del territorio, la nominación otorgada tanto a los naturales de la isla - el Pueblo Bubicomo al resto de africanos, fue la de negro esclavo. El fracaso de la primera empresa colonial española en la isla de Fernando Poo $(1778-1782)^{40}$ no impidió que continuasen zarpando barcos negreros con esclavos procedentes del continente africano que cruzaban el atlántico para ser usados como mano de obra esclava en las plantaciones americanas de los propietarios europeos ${ }^{41}$. La geografía del África atlántica se transformó. En la costa, controlada por comerciantes europeos y las élites negreras, surgió una "tierra de nadie" en un radio de 20 a $50 \mathrm{~km}$. La población emigraba al interior huyendo de los captores esclavistas que alimentaban la demanda de los comerciantes situados en el litoral. El padre claretiano Amador Martín, describiendo el carácter de los bubis que habitaban en el territorio insular, nos cuenta: "Este miedo al extranjero se debía seguramente a los intentos de la compañía "Cacheu e Cabo Verde" de obtener esclavos de la isla, de lo que tiene alguna referencia, a principios de este mismo siglo XVIII" (Martín del Molino, 1989: 36) ${ }^{42}$. Empero, este temor aparente no evitó que los bubis estableciesen relaciones comerciales con los ingleses que al parecer les abastecían de ñame "para los esclavos que compran en el Nuevo y Antiguo Calabra. Este comercio se hace a cambio de barretas de hierro, cascabeles, cuchillos, anzuelos y otras chucherías con la circunstancia de que los habitantes no gustan de ver a los europeos y mucho menos en disposición de penetrar tierra adentro" (Martín del Molino, 1989: 37).

La trata tendería una alfombra roja a los poderes coloniales y a la penetración europea que durante el siglo XIX conquistará África. Hasta entonces, a lo largo de los cuatro siglos que siguieron al primer contacto del encuentro colonial, el continente africano se convirtió en un productor de esclavos ${ }^{43}$ y la isla de Bioko sería un enclave importante en la ruta de dicho comercio. Sus costas meridionales serán habitadas "por un gran número de esclavos prófugos de Príncipe y São Tome. Estos infelices a quien trataban con un rigor excesivo los portugueses, gozan hoy de una entera libertad y viven en una especie de república que se gobierna por leyes particulares y sin dependencia alguna de las gentes del país" (Martín del Molino, 1989: 38). Este será el comienzo de diversos cambios demográficos que traerá la colonialidad del poder a la isla.

La manera de nombrar al Otr@ diferente cultural en el primer contacto del "encuentro colonial" marcará el inicio de los dos hechos institucionales que surgen en el mismo momento histórico en el que se crean ambas id-entidades geoculturales modernas, África y América. Los bubis, actores obligados desde los inicios del proceso de racialización, serán categorizados como negros esclavos en el imaginario colectivo occidental. La esclavitud, hasta entonces teñida de todos los colores - inclusive el blanco (Rivera, 1992) - adquirirá con la modernidad el color negro que a partir de entonces la va a caracterizar. Mientras, en el nuevo reino de España, la iglesia

40 Liliana Crespi en su artículo "En busca de un enclave esclavista. La expedición colonizadora a las islas de Fernando Poo y Annobon, en el Golfo de Guinea. (1778-1782)" nos da buena cuenta de esta primera malograda aventura colonial española y su intención de afrontar la trata esclavista para poder desligarse de los compromisos extranjeros y solventar los problemas de mano de obra en sus posesiones americanas (Crespi, 2010).

${ }_{41}$ Estos cargamentos de esclavos procedían del continente, a la isla arribaban los buques negreros para abastecerse.

42 Igualmente, Unzueta da constancia de los bubis de la época en la que pocos o casi ninguno vivían en el entonces Port Clarence ya que "permanecían alejados o recelosos" (Unzueta, 1947: 272).

43 Que no hay que confundir con el modo de producción esclavista. 
católica discute y otorga humanidad y alma a los indígenas americanos; los pueblos autóctonos que están bajo su administración colonial en la id-entidad geocultural llamada América. Lejos se encuentra todavía la gestión gubernamental del territorio insular; los bubis, como negros esclavos africanos, quedarán marginados del debate.

\subsection{La importancia del modelo de administración colonial y sus efectos a la hora de situar la otredad colonizada. Fernando Poo y la colonización española}

El final de la trata atlántica conllevó la ocupación efectiva del territorio. Sin embargo, hasta la mitad del siglo XIX, fue bastante escasa la atención que el gobierno español dirigió a sus territorios insulares africanos que en cambio sí atrajo el interés de la corona británica. Bajo su mando, esclavos liberados provenientes de Cuba y de otras partes de África pasaron a engrosar el número de habitantes de la isla de Fernando $\mathrm{Poo}^{44}$.

En 1841, la oferta de compra de Gran Bretaña parece despertar el interés hispano por el territorio africano. Como consecuencia de ello, en noviembre de 1842 el capitán de fragata don José de Lerena, a bordo del bergantín "Nervión", zarpa del Ferrol hacia la isla de Fernando Póo "con la curiosa orden de aplicar a los naturales las «Leyes de Indias», algo que a primera vista puede parecer anacrónico, pero que en las circunstancias del momento tenía un significado muy preciso: no se pensaba esclavizar a los indígenas." (Rodríguez, 2003: 238). Este dato es algo más que "curioso" y menos "anacrónico" de lo que a simple vista aparenta ser, como expresa Rodríguez. La legislación promulgada por los monarcas españoles para regular la vida social, política y económica entre los pobladores de la América hispana y por la que se les reconocían ciertos derechos a los indígenas es aplicada a1@s african@s. Un acto simbólico y burocrático que tres siglos atrás, 1542-1841, hubiese sido impensable: 1@s african@s comienzan a ser imaginados como indigenas por el poder colonial. Hasta entonces, para la corona española, los habitantes de África habían sido esclavos negros; ya fueran estos ladinos o bozales" ${ }^{45}$ (Rivera, 1992: 2). La "aplicación" de las "Leyes de Indias" ${ }^{46}$ fue el dispositivo burocrático y simbólico que las autoridades coloniales utilizaron para la dominación del territorio africano. El cambio en la manera de nombrar va parejo al ejercicio de la colonización efectiva en la región; el paso de la explotación a la dominación, el tránsito del esclavismo a

44 Dolores García Cantús en su tesis doctoral "Fernando Poo: una aventura colonial Española en el África occidental (1778-1900)" nos habla de una época dorada para los indígenas, literalmente afirma: "No olvidemos que, a fines del XVIII, la isla de Bioko (Fernando Poo) estaba pasando por una época "dorada" para los indígenas porque los posibles países colonizadores - Portugal, Inglaterra, España - aún no podían o no sabían cómo aprovechar sus riquezas con los mínimos costes. Es decir, la isla, hasta la segunda mitad del XIX, fue predominantemente utilizada por los navíos privados y piratería en general para abastecerse de agua (era uno de los pocos lugares del Golfo donde se encontraba en abundancia), descansar, etc. Y habitualmente las tripulaciones que desembarcaban en sus playas, nunca se adentraban hacia el interior" (Gracia, 2004: 58)

45 El Diccionario de la Real Academia Española define bozal como: "adj. Dicho de un esclavo negro: Que estaba recién sacado de su país. U. t. c. s.” y esclavo ladino: “m. y f. Esclavo que llevaba más de un año de esclavitud. (RAE, 2001). La importancia económica y política de esta diferencia para la época ha sido descrita por algunos autores, tal es el caso de García Cantús (2004). Según cita Rivera (1992), la primera vez que parece esta distinción entre esclavos bozales y ladinos es en la legislación sobre el Nuevo Mundo de 1501, sin especificar si dichos esclavos fuesen negros o no.

46 Las "Leyes de Indias" sufrieron diversas modificaciones. El 20 de noviembre de 1542, Carlos V convocó una junta de juristas que elaboraron las "Leyes Nuevas" en las que se prohibía la esclavitud de los aborígenes y la creación de nuevas encomiendas. 
la servidumbre. En definitiva, el giro de un hecho institucional a otro: de "lo negro" a "lo indígena" en África. Un claro ejemplo del viraje en los dos ejes de ese "específico patrón de poder" del que nos habla Quijano es el colectivo de esclavos negros cubanos que fueron traídos a la isla africana: el cambio en la clasificación social, ahora denominados indígenas, implicó un cambio en la explotación de la fuerza de trabajo, ahora asalariados ${ }^{47}$.

La soberanía española no se asienta hasta 1858, fecha en la que aparece el primer gobernador español y, con él, el reconocimiento y ordenamiento de la propiedad de la tierra en la colonia; tanto de los colonos establecidos como de las poblaciones autóctonas (Campos, 2004/2005). No sin reconocer antes que "la impenetrable maleza del bosque y demás condiciones especiales de esta localidad, hacen que no sea conocido el interior de la isla", según consta en un informe del consejo de gobierno citado por Campos (Campos, 2004/2005: 872). Con el nuevo siglo, España retomará el control del territorio insular y emprenderá su práctica colonizadora por medio de la explotación agrícola, para la cual necesitará mano de obra barata. La conquista del territorio ocasionará graves enfrentamientos con sus habitantes autóctonos los bubis_- los cuales, hasta entonces, habían logrado mantenerse al margen de la sociedad colonial con actos puntuales de resistencia (Toasije, 2013: 125). En la declaración que realizan como Pueblo Bubi, en el año 2013, ante el Mecanismo de Expertos de Cuestiones Indígenas en las Naciones Unidas (Ginebra) atestiguan:

Durante toda la época que España ocupó nuestra isla nuestros antepasados no dejaron de recordarles que no estaban dispuestos a perder su soberanía. España formó una guardia colonial compuesta de africanos traídos del continente. Se instalaron barreras militares a la entrada de todos los poblados de nuestra isla. Las continuas violaciones de nuestros derechos humanos de nuestro pueblo daban lugar a levantamientos que la guardia colonial reprimía con toda clase de violencia, incluso muertes. Se incendiaban los poblados con niños, mujeres y ancianos dentro.

(Declaración del Pueblo Bubi, Mecanismo de Expertos sobre Derechos Indígenas. Ginebra: 2013)

La expansión de las plantaciones de cacao provocó una considerable escasez de mano de obra que se intentó paliar a través del trabajo forzoso del Pueblo Bubi y, sobre todo, la emigración impuesta de braceros del continente hacia la isla, muchos de ellos nigerianos. Un crisol de habitantes va configurando la región complicando el panorama social y político, esta vez promovido por la administración colonial española ${ }^{48}$. Estas políticas migratorias tendrán consecuencias transcendentales en el panorama postcolonial, mas no nos adelantemos, de momento, a señalar el impacto que tuvo para la sociedad Bubi de la época estos movimientos de población que

47 Me estoy refiriendo a la primera inmigración forzosa que realizó el poder colonial español para la construcción de infraestructuras en el territorio; concretamente, al grupo de esclavos cubanos (1863-1886) cuyo traslado a la isla de Fernando Poo supuso la desvinculación jurídica de su condición esclava y la obtención de un salario, aunque se les imponía trabajar para el gobierno durante 5 años (Miranda, 1945).

48 Abelardo de Unzeta y Yuste miembro de la Real Sociedad Geográfica y de la Sociedad de los Estudios Internacionales y Coloniales describió la composición migrante de la isla en 1961 reconociendo a los bubis como el único pueblo originario (Unzueta y Yuste, 1961: 63-70) 
supusieron un riesgo para la población nativa y alteró gravemente los usos y costumbres locales ${ }^{49}$.

Durante la primera década del siglo XX se fortalece el Estado colonial, lo que supone un incremento de la diferencia colonial, si empleamos el léxico de Mignolo (Mignolo, 2000). Cada vez con mayor frecuencia, en el discurso social acerca del Otr@colonizad@african@ se le menta como indígena. La distinción jurídica entre indígenas y colonos permea todos los ámbitos sociales de la colonia, e inclusive fuera de ella. El modo de gobierno colonial español, inicialmente al estilo de gobierno indirecto heredado por los británicos (Campos 2004/2005: 867) ${ }^{50}$, contribuirá a la formación de una identidad indígena local originaria de la isla. La administración colonial irá construyendo la diferencia identitaria mediante el ordenamiento sobre la propiedad de la tierra ${ }^{51}$ y la regularización de la fuerza de trabajo ${ }^{52}$. A través de sus instituciones, "lo indígena" inunda lo formal y burocrático en la colonia: Una Curaduría, la versión moderna de la encomienda americana; el Instituto Colonial Indígena (1935), más tarde denominada Escuela Superior Indígena ESI, cuyo objetivo era formar una élite nativa de auxiliares administrativos subalternos; y la más importante de todas, el Patronato de Indígenas que en palabras del Gobernador General de Guinea Ecuatorial, Bonelli (1943-1949) es:

"la más bella quizá de nuestras Instituciones coloniales y la que tiene un papel más digno y más hermoso, porque su misión es defender, amparar, educar y proteger. Es tutor del indígena y, según la ley, completa su capacidad jurídica para todos los actos de su vida que exijan de él una capacidad que no tiene. Contratos, ventas, cesiones, traspasos de dominio...; todo ha de ser autorizado por el Patronato para que el acto pueda tener valor y efecto legal. El indígena no puede, aunque quiera, contraer deudas, porque el Patronato no autoriza préstamos onerosos; no puede firmar contratos leoninos; no puede hacer ventas ruinosas; no puede dilapidar su hacienda... En una palabra; está a cubierto de todo quebranto y sólo puede obrar aquello que le beneficie» Y llega a tanto nuestra actual legislación en este aspecto que si alguien a espaldas del Patronato hiciera préstamos a un indígena no emancipado, o firmara contrato de arrendamiento o trabajo, o compra o vendiera directamente, el acto es nulo y el indígena no viene obligado a cumplirlo, no sólo es nulo, sino que la parte contratante emancipada, cualquiera que sea su raza o color, incurre en delito y es acreedor a sanción.

(Bonelli, 1946)

Del viejo dispositivo burocrático colonial americano se crea la adaptación africana: el Patronato de Indígenas de los territorios españoles del Golfo de Guinea (19291959). Su entrada en la escena colonial coincide con lo que Sepa Bonaba ha deno-

49 Sepa Bonaba compara la gravedad de estos procesos migratorios para el Pueblo Bubi con la colonización misma. (Sepa Bonaba, 2011:174).

50 Campos mantiene que el gobierno colonial español en Fernando Poo fue al estilo del gobierno indirecto. Personalmente mantengo que este estilo de gobierno solo se dio al inicio de la colonización, ya que con el establecimiento del Patronato Indígena comienza un programa de asimilación de la población nativa al estilo del gobierno colonial directo francés (Sepa Bonaba, 2011: 276). Un ejemplo más de las dificultades que comportan la generalización de una realidad tan diversa y compleja como fueron los estilos de gobiernos coloniales.

51 Donde se define la tierra indígena como "las tierras que naturalmente ocupan los naturales" (Campos 2004/2005: 875).

52 Como aquellos que se resisten al trabajo forzoso por lo que los colonos se sienten obligados a traer braceros del continente (Campos, 2004/2005). 
minado la tercera fase del proyecto colonial cuyo objetivo principal era reformular los principios éticos y sociales de la población nativa para un dominio más efectivo y la imposición de un modelo de sociedad, esta vez sin métodos $\operatorname{coercitivos}^{53}$. Esta "versión africana" es un buen reflejo de la falta de un proyecto concreto para la zona (Sepa Bonaba, 2011: 268-270).

La imposición legal formal de este aparato institucional dividirá a los habitantes de la colonia en dos grandes grupos raciales: los blancos-europeos, colonizadores y los indígenas - negros-africanos - colonizados. Sin embargo, al igual que en otros lugares del África colonizada, en la realidad social de la isla de Bioko surgen dos tipos de súbditos indígenas: los inmigrantes y los autóctonos, lo cual "constituía una diferencia social y jurídica de primer orden" (Campos, 2004/2005: 882). Según el Gobernador General de los Territorios Españoles del Golfo de Guinea D. Juan Ma Bonelli Rubio:

Y así nos encontramos con que existe siempre una Curaduría indígena, cuya misión es, naturalmente, ejercer una acción tutora sobre los nativos, pero que defiende inexplicablemente la teoría de que el indígena de Fernando Póo no trabaje, y esto, como medida de protección a la raza, como si el trabajo fuera una fuente de depauperación superior a la del ocio, y como si no fuera infinitamente más deseable trabajar, que es una obligación impuesta al hombre por Dios mismo, que llevar una vida de holganza con la secuela de todos los vicios y miserias. Esto pensó un tiempo la Curaduría, pero a la vez, permitía y hasta estimulaba la recluta de braceros en nuestra zona continental concediendo de hecho una diferencia de trato al bubi y al pamue que no hay manera de explicar satisfactoriamente.

(Concepto de indígena en nuestra colonización de Guinea. Bonelli, Juan 1946.)

Este hecho diferencial, lejos de superarse, se agudizará social y políticamente en el proceso independentista y con posterioridad, no siempre positivamente. Hay que tener en cuenta que uno de los pilares sobre los que construirá el Pueblo Bubi su "nueva" identidad indígena será la defensa de su autoctonía. En la entrevista realizada a la lideresa bubi en relación a lo que significa ser indígena en África comenta:

...¿qué es lo que la gente entiende por indígenas? Si se trata de.., bueno...las primeras poblaciones, como lo llaman según donde...First People, los aborígenes, autóctonos. Yo creo que se debería reconocer, en África, lo que es en sí la persona indígena. Porque en nuestro caso, por ejemplo, en nuestra isla, nosotros, no hemos compartido más población, otra población que nosotros: los Bubis...

Las personas que no son Bubis, son personas extranjeras, son personas ajenas a lo que es nuestra isla...

Estos, los que siempre han estado ahí, desde miles y miles de años, estos son los indígenas de ese sitio. Yo como isleña, me extraña muchísimo que exista ese debate en África, no sé porqué, a lo mejor porque hemos estado un poco a espaldas del con-

53 Muchos son1@s autor@s que coinciden en la intención de la metrópoli de poner orden y límites a la avaricia de los colonos en los territorios insulares por lo que la regulación insular fue revestida de cierto paternalismo hacia 1@s nativ@s frente a los colonos. 
tinente. Ese debate lo he escuchado yo, aquí en Europa. Nosotros, cuando estamos allí se sabe perfectamente que nosotros los Bubis somos los autóctonos de allí.

(Entrevista realizada a Cecilia, a 1 de febrero de 2016, Madrid)

Con la Ley de Presupuestos de 1908, el gobierno español crea la Guardia Colonial, un cuerpo mixto, con la idea de sustituir a las fuerzas armadas que estaban establecidas en la zona ${ }^{54}$; sin embargo para el Pueblo Bubi tuvo un objetivo concreto. En palabras de Cecilia, representante bubi:

“[...] los españoles cuando fueron allí formaron su guardia colonial con mercenarios de aquí, del continente. Al principio eran africanos de todas partes, pero a partir de 1900 que los españoles vieron aquí este territorio, a partir de entonces, la Guardia Colonial española, ya era solamente de este sitio [ - señalando en el mapa territorio fang-_] y su misión era reprimir al Pueblo Bubi. Entonces, puedes imaginarte como, si has tenido como gente, o sea, los que te han estado reprimiendo, porque los han puesto un uniforme de militar, los han dado armas y que luego te dicen que vais a formar, que vais a ser del mismo país y encima les van a dar a ellos el poder que son más numerosos, el territorio de ellos es más grande y son más numerosos ( ...)

[...] son más el número que lo que es nosotros en la isla. Aparte de eso, son dos pueblos que no habían convivido tampoco. Porque yo nunca había visto gente de aquí [-refiriéndose a la zona continental del mapa- ]. La primera vez que yo vi a alguien de este sitio tenía yo 10 años o así, que luego empezaron a llegar a nuestra isla.

(Entrevista realizada a Cecilia, a 1 de febrero de 2016, Madrid)

La colonialidad del poder ejerce su patrón de dominación a pesar de que al inicio "la población autóctona apenas se integró en la nueva sociedad colonial, aunque sí participase de su economía" (Campos, 2004/2005: 870). La administración colonial de la isla de Fernando Poo se organizó en distritos a cuyo frente se encontraba el capitán - teniente que detentaba la autoridad máxima en la zona- desde donde controlaba el movimiento de los "indígenas" mediante pases a través de un sistema de puestos militares. Bajo el gobierno franquista, el gobierno colonial adquirió un carácter marcadamente militar, se impuso el español por encima de las lenguas locales y, a falta de presupuesto y funcionarios, se dejó en manos de los misioneros la "misión civilizadora" (Nerín, 2013: 55-54). El poder de los Pueblos Bubis declinó, mas lograron mantener su idiosincrasia identitaria frente a colonos e inmigrantes african@s - alguna de las veces con la ayuda del gobierno colonial_- Como consecuencia no esperada, la resistencia al poder consiguió organizar las diferentes monarquías existentes bajo lo que posteriormente se llamaría la Unión Bubi. Un proceso que se inició con el encuentro colonial: "La necesidad de defenderse frente a las intrusiones extranjeras fue una de las causas que impulsó los procesos de unificación y centralización" (Fernández, 2009). Ello permitirá a los bubis hablar con una sola voz en el proceso de independencia, a la vez que subrayará la diferencia colonial de "lo indígena", entendido como autóctono, en sus reivindicaciones "postcolonialistas" y contribuirá a su nueva reafirmación identitaria.

54 Estas eran: la guardia civil, los oficiales de aduanas y la infantería de marina. 


\subsection{Los procesos de independencia y la construcción de las identidades postcoloniales: de súbdit@s de la corona española a ciudadanos del Estado de Guinea Ecuatorial}

En 1926, España fusiona todas sus colonias del Golfo de Guinea en un solo territorio llamado Colonia de la Guinea Española; treinta años más tarde, el 21 de agosto de 1956, los territorios de ultramar pasan a ser considerados como Provincia del Golfo de Guinea que adquirirán el estatuto provincial el 30 de julio de 1959, adoptando oficialmente el nombre de Región Ecuatorial Española. A partir de este año, y debido a la presión internacional, comienza una progresiva "africanización de la administración" que consistirá en colocar a africanos al frente de los mandos directivos (Campos, 2003: 98). No obstante, se mantiene la división en dos provincias: una insular bajo el nombre de Fernando Poo y otra continental conocida como Río Muni. Precisamente, apoyándose en esta partición, el Pueblo Bubi pedirá reiteradamente al gobierno español durante el proceso de independencia que les constituya como un Estado-Nación independiente del área continental.

Forzado por Naciones Unidas, el régimen franquista continua su maquillaje político independentista decretando en 1963 la autonomía de la "Región Ecuatorial", una autonomía "falseada" — en palabras de Nerín — ya que el gobierno autónomo era nombrado a dedo por los españoles y buena parte de las decisiones las tomaban los técnicos del Estado (Nerín, 2013: 56) ${ }^{55}$.

Cuando se anuncia, en 1967, el futuro acceso a la independencia de Guinea Ecuatorial a lo largo de 1968, en la isla de Fernando Poo se había alcanzado el cenit del proyecto colonial, o lo que el sociólogo Sepa Bonaba ha denominado the colonial way of life; locución que expresa el extraordinario cambio que había experimentado la situación en la isla en relación a la etapa precolonial (Sepa Bonaba, 2011: 321). A pesar de ello, la identidad Bubi, como identidad autóctona de la isla, prevalece; buena muestra de ello es que ante el proceso de descolonización inminente, los Bötúkkus - jefes de poblado - de todas las comunidades Bubis de Fernando Poo crean la Unión Bubi con el objetivo de lograr el autogobierno. La cuestión de la aplicación del principio de auto-determinación en el territorio isleño fue uno de los temas importantes que estuvieron presentes en la Conferencia Constitucional, celebrada en el Palacio de Santa Cruz el 30 de octubre de 1967 (Campos, 2003: 109-110).

El 9 de junio de 1968, la Unión Bubi le hace llegar al ministro de Asuntos Exteriores una carta en la que expresan formalmente sus deseos de constituirse en un Estado autónomo y su temor a lo que pudiera ocurrirles si finalmente les "abandonan" fusionándoles en un solo Estado con los territorios continentales - Río Muni o Mbini-. En palabras de la Unión Bubi un nuevo colonialismo se cierne sobre su pueblo:

... no podéis señor ministro comprender al pueblo bubi, ni podéis nunca sospechar cuales pudieran ser la consecuencias de hermanarnos con hombres extraños a nuestra naturaleza, tan extraños como si fueran habitantes de otros mundos, hermandad artificial, falsa impuesta a causa de injerencias ajenas; y semilla de odio y de sangre. No necesitamos citar ejemplos de sobra conocidos, porque el sacrifico diario de vidas humanas en África es habitual. Porque otros hombres decidieron sentados en una

\footnotetext{
55 Un ejemplo más del rol que ha jugado Naciones Unidas en el proceso independentista y la constitución del nuevo Estado (Campos, 2003).
} 
mesa, hacer naciones sobre el papel, porque otros hombres "civilizados" desertaron a su obligación escogiendo el camino más fácil, el de abandonar a su suerte a estos otros hombres y borrar un colonialismo, siguiendo la moda, para crear otro colonialismo mil veces peor que aquel dejando al África negra abandonada a la Ley primitiva de sus bosque; la ley del más fuerte.

[...] Nos dirigimos a V.E. como presidente de la Conferencia Constitucional que está decidiendo nuestro futuro. Hemos enviado a nuestros representantes que son portavoces nuestros; pero no queremos que a nadie le quede la menor duda; habla en esta carta el pueblo entero de Fernando Poo; es el clamor unánime por nuestra vida; España puede abandonarnos si es que ha de ceder a las conveniencias del coro internacional, pero que nos abandone solos y nunca unidos a gente de otras costumbres, enemigos nuestros y más fuertes que nosotros.

(Carta de la Unión Bubi al Ministro de Asuntos Exteriores, 9 de junio de 1968)

Ningún llamado a la independencia del pueblo Bubi fue oído, a pesar de que eran bien conocidas sus reivindicaciones; su temor a una segunda colonización "mil veces peor" a la que hasta entonces habían sufrido se hacía presente en el sentir de la sociedad Bubi. La lideresa actual bubi refiriéndose a esta época declara: “...pero la gente sabía que iba a ir muy mal".

Ante el anuncio de que la colonia alcanzaría la independencia como una sola unidad política ${ }^{56}$ la Unión Bubi decide presentarse a las primeras y únicas elecciones democráticas que se celebran bajo los auspicios de la Administración Colonial Española y de las Naciones Unidas en septiembre de 1968. El resultado electoral en toda la colonia concluyó en un empate entre los dos candidatos más votados, lo que arrastró a Francisco Macías Nguema a un pacto con los representantes políticos del Pueblo Bubi para tomar la presidencia y evitar una segunda vuelta. Edmundo Bosió Dioco, representante de la Unión Bubi, acuerda con el futuro presidente un proceso de descentralización del Estado a partir de 1971 cuyo propósito será alcanzar una República Federal y abandonar la República Unitaria. Es el conocido "Pacto de Riebapúa" que no se cumplirá jamás.

El 12 de octubre de 1968, fecha simbólica en la historia colonial española, la Colonia de la Guinea Española obtiene la independencia como un solo Estado-Nación bajo el nombre de República de Guinea Ecuatorial. La declaración del documento del Pueblo Bubi presentado ante el Mecanismo de Expertos sobre los Derechos Indígenas expresa, una vez más, el sentimiento colectivo de desengaño y frustración ante el proceso independentista, un sentimiento similar al que tendrá, años más tarde, el pueblo saharaui:

En 1968 España descoloniza conjuntamente Rio Muni y la isla de Fernando Poo (hoy llamada isla de Bioko), dejándolos unidos como un país: Guinea Ecuatorial. Los Bubis de la isla de Bioko contrarios a la independencia conjunta con Rio Muni no

56 Las denuncias ante Naciones Unidas de los grupos independentistas a favor de la integración territorial acerca de las supuestas tácticas dilatorias y fomento de la separación del territorio isleño de Fernando Poo por parte del gobierno español, consiguieron que no se sometiera a consulta de referéndum la integridad del nuevo Estado (Campos, 2003: 110). 
fueron escuchados, y se vieron incorporados por la fuerza al nuevo Estado de Guinea Ecuatorial.

(Declaración del Pueblo Bubi, Mecanismo de Expertos sobre Derechos Indígenas, Ginebra: 2013)

Blas Piñar, político ultraderechista, procurador en las Cortes Españolas y consejero nacional del Movimiento por designación libre y directa del dictador Francisco Franco, relata en su libro Escritos para la historia (2000):

Estimo que es muy importante aclarar en qué consistían las desavenencias de la representación guineana tanto en la conferencia constitucional, en Madrid, como en la Organización de Naciones Unidas. Para los “bubis”, Fernando Poo no tenía nada que ver con Río Muni. Así lo había reconocido el Régimen al establecer dos provincias diferentes en el año 1959. Por lo tanto, de proclamarse la independencia debía ser de dos naciones distintas. Para los pamúes, la independencia había de ser con respecto a una sola nación y con un gobierno central fuerte. Para algunos bubis y pamúes podía aceptarse la tesis de una sola nación, pero con dos provincias autónomas para gobernarse a sí mismas en los asuntos internos. Se trataba, escribía José María Carrascal en Pueblo, del 9 de julio de 1958, de un "asunto sucio y triste". Sólo hubo unanimidad en que la independencia sería a partir del 12 de octubre de 1968, para así poner de manifiesto la integración de Guinea ecuatorial en la comunidad de pueblos hispánicos.

(Piñar, 2000)

En su edición de la mañana, el periódico ABC (1968: 56) de la época publica la noticia alabando la "labor civilizadora" de España en el continente africano y anuncia que "Guinea Ecuatorial, en un proceso coherente e ininterrumpido, con la ayuda de España, ha escalado los peldaños de su plena soberanía“. En el tono nacionalista característico de la dictadura franquista, el columnista escribe: "La íntima relación entre la epopeya española en América y la presencia española en África ecuatorial vuelve a manifestarse en las horas memorativas de la Hispanidad como unidad política activa", un reconocimiento explícito al nacimiento de la colonialidad del poder 500 años atrás. Por supuesto, se omite la difícil situación en la que queda el Pueblo Bubi de la isla de Fernando Poo. Envuelto en una retórica triunfalista lo que políticamente fue considerado una pérdida, el artículo concluye: "España, que concibió a una comunidad de pueblos el 12 de octubre de 1492, en este 12 de octubre de 1968 alumbra con el gozo profundo de las madres una nueva Nación, un nuevo miembro para la gran familia, a veces mestiza y siempre católica, de la Hispanidad". La "Hispanidad", una de las banderas del eurocentrismo mediterráneo, fundó el mito de la existencia de una identidad geocultural llamada España anterior y posterior a la constitución del patrón de poder hegemónico que construyó el imperio y a cuya empresa "civilizatoria" la bautizó como "Hispanidad"57.

El "día de la Raza", día de la fiesta nacional española y pendón de una de las tres líneas de clasificación social que articula la colonialidad del poder quijania-

57 Las metáforas que comparan la "Hispanidad" con una "familia", donde la madre es la identidad geocultural España y sus hijos las colonias, inundan los discursos nacionalistas: "Habéis perfeccionado vuestra independencia, significativamente, en el día de la gran fiesta familiar, el Día de la Hispanidad.” (Las ceremonias de la independencia de Guinea Ecuatorial. Discurso del señor Fraga Iribarne, 13 de octubre de 1968). 
na, la República de Guinea Ecuatorial adquiere la independencia. Francisco Macías Nguema, originario de Mongomo - ciudad ubicada en el área continental frontera con Gabón-, lidera como presidente un gobierno de coalición junto con el líder de MONALIGE y Edmundo Bosio Dioco — líder de la Unión Bubi-que es nombrado Vicepresidente de la República.

Al transcurrir los tres años que dictaba el "Pacto de Riebapúa" los Bubis reclaman el proceso de autonomía de su región. La respuesta del presidente Macías es clara y contundente: "Cuando firmé el pacto yo no era presidente, ahora soy el Presidente de la República. Como Presidente, no quiero volver a oír ese asunto. Os sugiero no vuelvan a hablarme de ese acuerdo. Los pactos se firman para no cumplirse" (Chicampo, 2013). A partir de ese momento el aparato represor irá in crescendo, la lideresa bubi entrevistada afirma "Estos sustituyeron a los españoles en cuanto a opresión, entonces estos [refiriéndose al primer gobierno independiente de Guinea Ecuatorial] acabaron con esa élite de la Unión Bubi, los exterminaron" 58 . Ello no evitará que en los discursos del nuevo dictador fang el "Indigenismo de Estado" esté presente, como bien muestra el folleto propagandístico del PUN - Partido Único Nacional - de 1972 explicando en qué se caracteriza el sistema colonialista; el punto tres al respecto dice textualmente:

" $3^{\circ}$.- No reconoce la personalidad ni el derecho de los indígenas, destruyendo, embotando y prohibiendo con severas sanciones, la supuesta tendencia manifiesta de los aborígenes, que tengan por objeto la formación de su plena conciencia nacional."

(PUN, 1972: 16)

Aborigen, indígena, negro, nativo o autóctono, todos son sinónimos que se contraponen a colono blanco y sirven para la construcción de la nueva identidad nacional guineana que engulle las diversidades culturales en un nuevo Estado-Nación postcolonial. En este contexto se comprende la declaración del pueblo indígena Bubi de 2013 que reza: "Guinea Ecuatorial es uno de esos países llamados artificiales porque fueron creados por los colonizadores uniendo territorios dispersos de pueblos diferentes con lenguas y costumbres diferentes" (Declaración del Pueblo Bubi, 2013).

Su nuevo presidente erige una dictadura de partido único hasta 1979. La Constitución promulgada en 1973 instaura un Estado único anulando el estatuto de federación que regía entre el territorio insular y el continental. Entre 1974 y 1979, Felipe Beta Tobachi, el autor de la "lista negra" 59 y tras iniciar una represión sangrienta contra el Pueblo Bubi, ejerce de gobernador en la isla (Chicampo, 2013).

El golpe de Estado de 1979 liderado por Teodoro Obiang Nguema Mbasogo sobrino del anterior presidente, no mejora en nada la situación de la comunidad bubi.

Ambos dictadores elaboran una serie de constituciones sucesivas en las que, escalonadamente, se van mermando los derechos reconocidos a los bubis; en ellos se nos niega el sufragio pasivo y el tener partido político propio; se nos discrimina y excluye de las

58 Habla del periodo concreto desde 1968 a 1975 (Entrevista a Cecilia, lideresa bubi, realizada en Madrid el 1 de febrero de 2016). E1 9 de febrero de 1975 fue asesinado Edmundo Bosio Dioco.

59 Según Chicampo, Coordinador General del MAIB - Movimiento para la Autodeterminación de la isla de Bioko_, en la Lista Negra del poblado de Basakato del Este — Isla de Bioko_- "figuraban 219 detenidos entre hombres y mujeres: de ellos murieron 183 y sobrevivieron 36" (Chicampo, 2013: 2) 
instituciones, llegando a obligarnos a expresarnos en lengua fang siendo el español la lengua oficial.

(Declaración del Pueblo Bubi, Foro de Cuestiones Indígenas, Nueva York: 2013)

Al igual que ocurriese en los años 60, donde el contacto con otros grupos independentistas africanos en Naciones Unidas ayudó a la elaboración del discurso y a la acción independentista de los representantes que acudieron a Nueva York (Campos 2003: 102-103), los representantes actuales bubis intercambiarán experiencias y estrategias con otros grupos indígenas del mundo en el Foro de Cuestiones Indígenas -Nueva York - y en el Mecanismo de Expertos para Cuestiones Indígenas - Ginebra-. Confiando en la presión exterior, el Pueblo Bubi, de una manera u otra, se ha hecho oír en el espacio internacional. En la entrevista realizada en Madrid, Cecilia afirma: "Las Naciones Unidas no pueden decir que no sabe lo que esta pasando con el Pueblo Bubi porque, mucho tiempo atrás, gente, bubis, grupos, han ido...diciendo las cosas. Y hay informes de esos relatores" (Cecilia, Lideresa bubi, 2016), refiriéndose a los informes de los Relatores de Derechos Humanos de Naciones Unidas en los que se hacen constar la situación del Pueblo Bubi, entre otras, en el recién nacido Estado africano de Guinea Ecuatorial ${ }^{60}$.

El Pueblo Bubi siguen sufriendo como sujetos coloniales la explotación del capitalismo colonial/moderno y continúan en la actualidad soportando una situación subalterna en su territorio. "Otro colonialismo", un colonialismo interno, cuyo origen fue la ingeniería social colonial concebida para la mejor explotación de los recursos del territorio, es consolidado por las complejas relaciones de poder del capitalismo global actual, haciendo más difícil que nunca la posibilidad del reconocimiento de los derechosde1@s sujet@scolonizad@s.

...hay una violación continua de nuestros derechos humanos. Sufrimos un exterminio sistemático. Hay una persecución sangrienta a nuestro pueblo cada vez que reclamamos nuestro derecho de autodeterminación. Se nos han confiscado nuestras tierras de cultivo.

... Se destruyen nuestros bosques sagrados. Nuestras niñas sufren abusos sexuales a consecuencia de la masiva e incontrolada llegada de gente venida del continente y de todas partes. No tenemos libertad de circulación. A la entrada de cada uno de nuestras aldeas hay barreras militares, que existen desde la ocupación colonial. Somos un pueblo milenario en grave peligro de extinción.

(Declaración del Pueblo Bubi, Mecanismo de Experto de Cuestiones Indígenas, Ginebra: 2013)

Las figuras jurídicas de la población negro-africana que se construyeron bajo el poder metropolitano —nativos-bubis, fernandinos, procedentes de poblaciones españolas y braceros reclutados de los países africanos - reflejan un modelo de sociedad de "clarísimo enfoque racista", cerrando las posibilidades de convivencia in-

60 Tan sólo en la página web de la Oficina del Alto Comisionado de las Naciones Unidas para los Derechos Humanos se pueden consultar 120 documentos a cerca de la situación de los Derechos Humanos del Estado de Guinea Ecuatorial desde 1982. 
terracial en armonía (Sepa Bonaba, 2011: 284). Estas rivalidades interétnicas creadas y alimentadas por la colonialidad del poder se convertirán en un odio profundo del nuevo poder postcolonial hacia la comunidad Bubi. El 27 de noviembre del 2013, en el Grupo de Trabajo para el Foro sobre Empresas y Derechos Humanos, una delegación declaraba:

[...] Somos víctimas de un plan de dominación mediante extermino y un genocidio sistemático.No sólo nuestro pueblo está seriamente amenazado de extinguirse, sino que también nuestra isla está seriamente amenazada por el deterioro del medio ambiente y la biodiversidad. Nuestras zonas de reservas naturales protegidas (el pico de Bailé, el pico de Biao y la Gran Caldera de Luba) están siendo expoliadas [...]

El descubrimiento de petróleo en el nuevo Estado postcolonial y su explotación ha dificultado, más si cabe, las posibilidades de independencia o mejora de la situación del Pueblo Bubi. Uno de los tantos casos donde el proceso el independencia no ha implicado la descolonización del territorio.

Los Bubis de la isla de Bioko hemos informado varias veces ante las Naciones Unidas que estamos colonizados. La misma situación de dominación, discriminación, estado de subordinación, invasión y ocupación de nuestra isla que vivieron nuestros padre y abuelos durante la anterior colonización, la generación actual de Bubis la estamos viviendo respecto a los colonizadores actuales: los Fangs. Un pueblo continental al que pertenece el actual régimen dictatorial militar. Este mismo pueblo fang ya formó parte de la guardia colonial española, que los españoles utilizaban para reprimir al pueblo bubi en los casos de levantamiento y propuesta.

(Declaración Pueblo Indígena de la Isla de Bioko, Ginebra, 27 de noviembre de 2013)

\section{Conclusiones}

En este escrito he tratado de desentrañar la carga histórica ideológica y política que esconde la negación de la existencia de indígenas en África, poniendo como ejemplo el caso de los Bubis de la isla de Bioko. Al igual que otros pueblos africanos, el Pueblo Bubi ha ido adaptándose a las duras circunstancias sobrevenidas con la colonización europea, sin renunciar por ello a una identidad propia. Ha tenido que aprender los nuevos lenguajes y formas de dominación que trajo consigo el desarrollo del patrón mundial del poder capitalista, en palabras de Quijano, y crear nuevas estrategias defensivas ante el nuevo Modo de Producción de Representación Imperial. No obstante, como dijo Foucault (1978) "Donde hay poder también hay resistencia al poder" por lo que a la vez que se crean las nuevas tecnologías de dominación, surgen espacios defensivos y contra hegemónicos. En el espacio transnacional, Naciones Unidas ha jugado ese doble papel. En nuestro caso, si bien es indudable el rol que jugó en el "proceso de descolonización" del que se constituyó el Estado de Guinea Ecuatorial, como he afirmado anteriormente, no es menos cierto que terminaron prevaleciendo las fronteras trazadas por el viejo colonialismo europeo ante la defensa de los intereses del nuevo poder colonial que impuso su discurso nacionalista, pasando a formar parte a partir de entonces del "club de Estados" y ejerciendo su poder colonizador. 
Nuevos espacios de resistencia se abren en el complejo trazado de poder que son las Naciones Unidas. A finales de 1993, y de conformidad con la recomendación de la Conferencia Mundial de Derechos Humanos, la Asamblea General proclama el primer Decenio Internacional de las Poblaciones Indígenas del Mundo (1995-2004) al que le seguirá el Segundo Decenio Internacional de las Poblaciones Indígenas del Mundo (2005-2014). Durante este tiempo se crean espacios de confluencia global donde Pueblos Indígenas de todas partes del planeta acuden a expresar sus demandas y su situación subalterna. Resultado del trabajo conjunto entre ellos y otras instituciones es la Declaración de los Derechos de las Poblaciones Indígenas aprobada por la Asamblea General en el año 2007. Sin embargo, tan importante, o más preponderante todavía, han sido los cambios significativos que se producirán en el lenguaje a raíz de las confluencias de las distintas resistencia de aquellos pueblos que continúan bajo el yugo colonizador. Esta segunda ola de la indigenidad parte del presupuesto de que la descolonización es un proceso inacabado y la indigenidad es una política de la resistencia ((Venkateswar, Hughes, Kidd et al., 2011: 2).

El error más grave en el que suelen caer aquell@s que niegan el derecho a la condición indígena de los african@s es el de interpretar la identidad desde un perspectiva esencialista. Considerar cualquier tipo de identidad como inmanente al ser supone seguir reproduciendo, desde ese lugar epistémico de enunciación del poder colonial, la colonialidad del poder; caer en su trampa. Resulta tan necio entender la identidad indígena de manera esencialista como concebir la identidad occidental del mismo modo. La identidad indígena africana es, al igual que toda identidad indígena actual, una identidad política, postcolonial, contemporánea, y global (Juanena, J-A, 2010); lo que nos obliga partir de una mirada constructivista.

La identidad indígena es política puesto que se construye bajo y por el conflicto social. Como tal, solo se puede explicar dentro de los contextos socio-políticos en los que surge. Es necesario dar cuenta de las luchas de y por el poder que la constituyen. Como identidad colectiva genera una conciencia en y para sí expresada en unnosotr@s diferenciado. Por otro lado, el adjetivo postcolonial es especialmente significativo en nuestro caso, ya que nos sitúa en el contexto geográfico e histórico. Geográficamente nos ubica en los territorios conquistados por el poder colonial e históricamente nos instala en el proceso de la colonización (Young, 2001); este adjetivo es relevante por la centralidad que adquiere el hecho social inmaterial de la colonización. Asimismo, ser una identidad contemporánea ${ }^{61}$ significa que ha tenido la capacidad de adaptarse a las condiciones políticas actuales. El término indígena ha ido viajando a través del tiempo adquiriendo distintos significados. Si bien durante siglos, marcados por el colonialismo, "lo indio" en su condición subalterna ha sufrido un proceso de peyoritivización ${ }^{62}$; hoy en día esta siendo re-evaluado. El

${ }^{61}$ En el sentido de "ir con su tiempo", lo cual no tiene las connotaciones de la palabra moderno que contiene un "aquí" y "ahora". Con-el-tiempo ya sea este moderno o antiguo.

62 Braidotti (2004) se refiere a la experiencia simbólica de peyorativización como la que sufren aquellos sujetos empíricos que constituyen un "Otro" que es "diferente de" la norma esperada: en tanto que tal el/la es a la vez el referente empírico como el signo simbólico de lo peyorativo. Y continúa esta autora "No obstante, el otro devaluado funciona al mismo tiempo como configurador crítico de significado. La otredad devaluada o peyorativizada organiza las diferencias en una escala jerárquica que da lugar a la conducción y gobernabilidad de todos los grados de las diferencias sociales. Por extensión, el uso peyorativo de las diferencias no es accidental, sino más bien estructuralmente necesario para el sistema falogocéntrico de significado y para el orden social y el poder que lo sustentan.” (Braidotti, 2004: 190). 
nuevo Movimiento Social Planetario Indígena ${ }^{63}$, en un proceso de enaltecimiento, ha re-semantizado positivamente la vieja categoría indígena dotándola de orgullo identitario y dirigiéndola hacia la conquista de la autodeterminación cultural y política. Una lucha fortalecida tras la aprobación por Naciones Unidas de la Declaración de los Derechos de los Pueblos Indígenas en 2007. Y por último, es una identidad global ya que ha sufrido y sufre con diferentes sujetos colectivos alrededor de todo el globo la experiencia de la colonización. Desde sus distintas realidades consensuan una manera distinta de estar en el mundo cooperando con otros actores contra-hegemónicos de la resistencia global organizada, cuyo objetivo es dar una respuesta al poder hegemónico global. El nuevo ser Indígena, surgido de la dialéctica de la colonización, reivindica su derecho a relatarse, imaginarse y pensarse como sujeto colectivo que pone en práctica su propio modo de representación tras siglos de represión colonial, y en respuesta a las identidades colectivas inventadas por occidente.

La función integradora que pretendieron cumplir los Estados-Nación se diluye en el nuevo mundo globalizado. "Nuevas" comunidades imaginadas resurgen en el panorama internacional con nuevas conceptualizaciones del mundo más transnacional que occidental (Young, 2001). Una parte de ese llamado Cuarto Mundo, que son las minorías culturales indígenas, reaparece en el escenario global. En la era de las diferencias, en oposición a los años de igualitarismo, la Otredad devaluada a la que fueron confinadas en el pasado es ahora re-significada en el proceso identitario y se convierte en el deseo ontológico, el deseo de ser. No es simplemente que la crítica postcolonial denuncie las nuevas condiciones materiales y culturales a las que se ven sometidos los subalternos, sino que además, esos recuerdos marginales de la colonización, subyugados, esos recuerdos de las minorías, contramemorias alternativas, como las denominó Foucault (1977), son ahora re-escritos por1@s sujet@s subaltern@s colonizad@s ayudándoles a restablecer el orgullo macerado. Las “nuevas" identidades políticas postcoloniales retoñan re-construidas a través del nuevo orgullo identitario (Juanena, 2010).

La ingeniería social imperialista que se utilizó bajo la colonización africana, basada en una lógica legal formal más compleja que la que dio inicio a la colonialidad del poder en América, revisten los casos de los Pueblos Indígenas africanos de especial dificultad. El orden social imperial del colonialismo europeo ha dejado una herencia a los pueblos originarios africanos que eclipsa y obstaculiza aún más el tortuoso camino que les pueda conducir hacia la salida del lugar subalterno al que han sido relegados. El estudio del contexto histórico y los proceso de dominación ayudan a desvelar la condición subyugada a la que han sido desplazados. A ello hay que sumar la realidad compleja que domina la globalización en curso: ayudados por los poderes económicos actuales, nuevos actores reproducen el patrón mundial del poder capitalista.

Y sin embargo, al calor de los nuevos movimientos sociales de la resistencia, aprovechando los resquicios que encuentran en el camino, los Pueblos Indígenas

63 En sintonía con el concepto de Ángel Calle (2003) acerca de los Nuevos Movimientos Sociales Globales (NMSG), he querido distinguir a los Nuevos Movimientos Sociales Planetaristas o Planetarios (NMSP) como aquellos que tienen un concepto íntegro del planeta, inclusive de los seres "no vivos" según son considerados por la ciencia convencional. Entrarían en esta clasificación Movimientos Sociales tales como: el ecofeminismo, movimiento indígena, algunos ecologistas, los defensores de Gaia, etc. Todos ellos tienen en común su defensa a una alternativa de vida planetaria que incluye a todo el planeta. La "globalidad" de los NMSG tan solo hace referencia a la coordinación de personas a escala internacional, global. 
africanos van abriéndose paso, poniendo en escena la historia de occidente enredada en los entramados de su propio lenguaje. Un lenguaje que nos habla del patrón del poder capitalista. Se les dijo que eran esclavos; se les dijo que eran negros; se les dijo que era súbditos de reyes que desconocían; se les dijo que eran indígenas, sin saber qué significaba; se les dijo que pertenecían a un Estado y debían de cumplir sus fronteras y sus leyes, leyes que ignoraban; ahora ell@s dicen "somos", en una lucha que jamás abandonaron.

De todas maneras como estamos ahora nosotras reclamando, siempre hemos reclamado como Pueblo Bubi, siempre lo hemos reclamado así. Entonces ahora que existe esta declaración, lógicamente estamos ahora con esta declaración en la mano, reclamando. ¿Por qué? Porque esta declaración del artículo 37 reconoce lo de los tratados. Que hay que respetarlos, esos tratados que se hicieron siglos atrás. Entonces ahora con la declaración, claro que reivindicamos nuestros derechos indígenas por la declaración.

(Lideresa bubi ante la pregunta ¿Por qué acudieron a los organismos internacionales como pueblo Indígena? Madrid, 2015)

\section{Referencias bibliográficas}

2013. Declaración del Pueblo Bubi, en $7^{\mathrm{a}}$ Sesión del Mecanismo de Expertos sobre Derechos Indígenas. Ginebra: ONU. http://www.docip.org/Documentacion-en-linea.32+ M57d0acf4f16.0.html. [Fecha de consulta: 3 mayo 2016].

2013. Declaración del Pueblo Bubi en $12^{\text {a }}$ Sesión del Foro de Cuestiones Indígenas, Nueva York: ONU. http://www.docip.org/Documentacion-en-linea.32+M57d0acf4f16.0.html. [Fecha de consulta: 3 mayo 2016].

2015. Declaración del Pueblo Bubi en $14^{\mathrm{a}}$ Sesión del Foro de Cuestiones Indígenas, Nueva York: ONU.

Ander-Egg, Ezequiel (1992). Técnicas de investigación social (22 ${ }^{\mathrm{a}}$ ed.). Buenos Aires: Humanitas.

Asad, Talad (1973). Antropology \& the Colonial Encounter. Atlantic Highlands, N. J.: Ithaca Press and Humanities Press.

Bayart, Jean-François; Geschiere, Peter y Nyamjoh, Francis (2001). “Autochtonie, démocratie et citoyenneté en Afrique". Critique internationale, 10: 177-194.

Bellier, Irène (2011a). "La revitalización de los pueblos indígenas en la globalización" en Bilbao, Alejando. Creación, Identidad y Mundo en los Estados de la Globalización. Campo psíquico y Lazo Social. Santiago de Chile: Editions Universitaires de Valparaíso, 43-58.

Bellier, Irène (2011b). "Misunderstanding of autochthony vis-à-vis the question of indigenous peoples". Social Anthropology, 19, (2): 204-206. doi:10.1111/j.1469-8676.2011.00149.x

Bellier, Irène (2011c). ““'Response to Peter Geshiere”. Social Anthropology, 19, (2): 209-211. doi: $10.1111 / \mathrm{j} .1469-8676.2011 .00151 . \mathrm{x}$

Bonelli, Juan Ma 17 de noviembre de 1946 Concepto del indígena en nuestra colonización de Guinea En el Instituto de Estudios Políticos Internacionales y Coloniales de Madrid. ASODAGUE http://www.asodegue.org/hcdfld.461217.htm

Braidotti, Rosi (2004). Feminismo, diferencia sexual y subjetividad nómade. Barcelona: Editorial Gedisa.

Calle, Ángel (2003). "Los nuevos movimientos globales" Papeles del CEIC, 7 : 1-13. http:// www.identidadcolectiva.es/pdf/7.pdf [Fecha de consulta: 1 septiembre 2016]. 
Campos, Alicia (2003). "The Decolonization of Equatorial Guinea: The relevance of the International Factor", The Journal of African History, 4 (1): 95-116.

- (2004/2005) "Colonia, Derecho y Territorio en el Golfo de Guinea: Tensiones del colonialismo español en el siglo XX." Quaderni Fiorentini per la Storia del Pensiero Giuridico Moderno 33/34: 865-898.

Chabal, Patrick (2011). África: la politica de sufrir y reír. Barcelona: Oozebap.

Crespi, Liliana (2010). "En busca de un enclave esclavista. La expedición colonizadora a las islas de Fernando Poo y Annobon, en el Golfo de Guinea. (1778-1782)" Revista Digital Estudios Históricos 4, 11. http://www.estudioshistoricos.org/edicion_4/liliana-crespi.pdf

Del Cantillo, Alejandro (1843). Tratados de Paz y de Comercio. Desde el año 1700 hasta el día. Madrid: Imprenta de Alegría y Charlain. https://play.google.com/books/reader?id=e rsCAAAAYAAJ\&printsec $=$ frontcover\&output=reader\&hl=es\&pg=GBS.PP11 [Fecha de consulta: 1 septiembre 2016].

Fernández, Nuria (2009) "Jefaturas, reinado y poder colonial: evolución de la estructura política de los bubis en la isla de Bioko" en Historias de la colonia. Hojas informativas. Ed: ASODEGE http://www.asodegue.org/junio2209h.htm [Fecha de consulta: 1 septiembre 2016].

Fraga Iribarne. "Las ceremonias de la independencia de Guinea Ecuatorial". 13-octubre-1968. La Vanguardia Española, 6.

Foucault, Michel (1977) Nietzsche, la genealogía, la historia. Valencia: Pre-Textos.

Foucault, Michel (1978). Microfísica del poder. Madrid: La Piqueta.

García Cantús, Dolores (2004). Fernando Poo: una aventura colonial española en el África Occidental (1778-1900).Tesis doctoral. Facultad de Ciencias Políticas y Sociología. Universidad Complutense de Madrid.

Geshiere, Peter (2011a). "Response to Irène Bellier". Social Anthropology, 19, (2): 207-209. doi: 10.1111/j.1469-8676.2011.00150.x

Geshiere, Peter (2011b). "Response to Irène Bellier". Social Anthropology, 19, (2): 211-212. doi: 10.1111/j.1469-8676.2011.00152.x

Goldschmidt, Walter(1968). “Antropología: Estudio de la Sociedad moderna” en Enciclopedia Internacional de las Ciencias Sociales. Madrid: Aguilar.

Guinea en el día de la Hispanidad. 12-octubre-1968. ABC, 56.

Hobsbawn, Eric y Ranger, Terence (2002). La invención de la tradición. Barcelona: Crítica. Inieta, Ferrán (2000[1998]). Kuma. Historia del África negra. Barcelona: edicions bellaterra. Juanena, J-A Coro (2010). Investigando al otro diferente cultural. Un modelo metodológico no etnocéntrico. El estudio de caso: La identidad de las Mujeres Indígenas en los organismos internacionales. Tesis doctoral. Facultad de Ciencias de la Comunicación. Universidad Rey Juan Carlos.

Juanena, J-A Coro (2013). “Antropología social: catarsis de una disciplina” en Doncel, Luis; Gutierrez, Tomás; Juanena, J-A Coro (Coords.) Sociología especializadas II. Madrid: Dykinson, 191-209.

Kuper, Adam (2003). "The return of the native" Current Anthropology, 44, (3): 389-402

Korsbaek, Leif y Sámano, Miguel Ángel (2007). "El indigenismo en México: antecedentes y actualidad". Re Ximhai, 3 (1): 195-224.

Lacan, Jacques (1972). Conferencia de Lacan en Lovaina, el 13 de octubre de 1972. Conferencia. Universidad Católica de Lovaina. En [1] Jacques Lacan. Grandes pensadores del siglo XX https://youtu.be/C9yN0Ggij78 [Fecha de consulta: 1 septiembre 2016].

Martín del Molino, Amador (1989). Los bubis, ritos y creencias. Malabo: Centro Cultural Hispano Guineano. 
Mignolo, Walter D. (2000). Local histories/Global designs. Coloniality, Subaltern knowledges, and border thinking. Princeton, New Jersey: Princenton University Press.

Miranda, Agustín (1945). Leyes coloniales. Legislación de los Territorios Españoles del Glofo de Guinea. Madrid: Sucesores de Rivadeneyra.

Nerín, Gustau (2013). "Un pie en África negra" en La aventura de la historia, 172. Madrid: Arlanza, 52-57.

Piñar, Blas (2000). Escritos para la historia Madrid: FN editorial. http://www.maalla.es/ Libros/Escrito\%20para\%201a\%20Historia.pdf

Pun, Partido Único Nacional (1972). Formación Politica Anticolonialista. Bata: La libertad. https://docs.google.com/file/d/0B6Bw-KX3F6HXMFVyVWFtT181MDA/edit?pref= 2\&pli=1[Fecha de consulta: 1 septiembre 2016].

Quijano, Aníbal (2000a). "Colonialidad del poder, eurocentrismo y América Latina”, en W. Lander (Comp), La colonialidad del saber: eurocentrismo y ciencias sociales. Perspectivas Latinoamericanas. Buenos Aires: CLACSO, Consejo Latinoamericano de Ciencias Sociales, 246-274. http://bibliotecavirtual.clacso.org.ar/ar/libros/lander/quijano. $\mathrm{rtf}$

Quijano, Aníbal (2000b). “Colonialidad del Poder y Clasificación Social”. Journal of WorldSystems Research, VI, 2, summer/fall: 342-386.

Real Academia Española (RAE) (2001). Real diccionario de la lengua española (22 ${ }^{\mathrm{a}}$ ed.) http://dle.rae.es/ [Fecha de consulta: 1 septiembre 2016].

Rivera Pagan, Luis N. (1992). "Bartolome de las Casa y la esclavitud africana”, en Meléndez, G. (Ed.) Sentido Histórico del V Centenario (1492-1992): 16th Simposio de CEHILA (1989: Santo Domingo, Dominican Republic). Costa Rica: DEI, 63-84.

Rodríguez, González, Agustín (2003). "Prólogo a una colonia: la estación naval de Guinea (1858-1900) ". Cuadernos de Historia Contemporánea, 237 (núm. Extraordinario): 237246.

Saugestad, Sidsel (2001). The inconvenient indigenous: remote area development in Botswana, donor assistance, and the first people of the Kalahari. Uppsala: Nordiska Afrikainstitutet.

Sepa Bonaba, Edmundo (2011). España en la isla de Fernando Poo (1843-1968). Colonización y fragmentación de la sociedad bubi. Barcelona: Icaria.

Spivak, Gayatri C. (1993). "En a Word: Interview" en Rooney, Helen (Ed.), Outside in the Teaching Machine. Nueva York: Routledge.

Searle, John R. (1997). La construcción de la realidad social. Barcelona: Paidós Ibérica.

Toasijé, Antumi (2013). Si me preguntáis por el panafricanismo y la afrocentricidad: artículos, conferencias, discursos y entrevistas. Madrid: Wanafrica.

Unzueta y Yuste, Abelardo (1961). "Etnografía de Guinea. Algunos grupos inmigrantes de Fernando Poo". África 5, 77/78, V/VI (1948): 196-99.

Venkateswar, Hughes, Kidd et al. (2011). "Introduction" en Venkateswar, Sita y Hughes, Emma (Eds.), The politics of the indigeneity. Dialogues and reflections on indigenous activism. Nueva York: Zed Books, 1-15.

Wallerstein, Immanuel (2005). Análisis del sistema mundo. México: Siglo XXI.

Weber, Max (1964). Economía y sociedad. Esbozo de sociología comprensiva (1ª ed. 1922). México: Fondo de cultura económica.

Woolgar, Steve (1991). Ciencia: Abriendo la caja negra. Barcelona: Ánthropos.

Young, Robert J. C. (2001). Postcolonialism. An historical introduction. Oxford: Blackwell Publishers Ltd. 